UNIVERSIDADE FEDERAL DE GOIÁS

FACULDADE DE CIÊNCIAS HUMANAS E FILOSOFIA DEPARTAMENTO DE CIÊNCIAS SOCIAIS

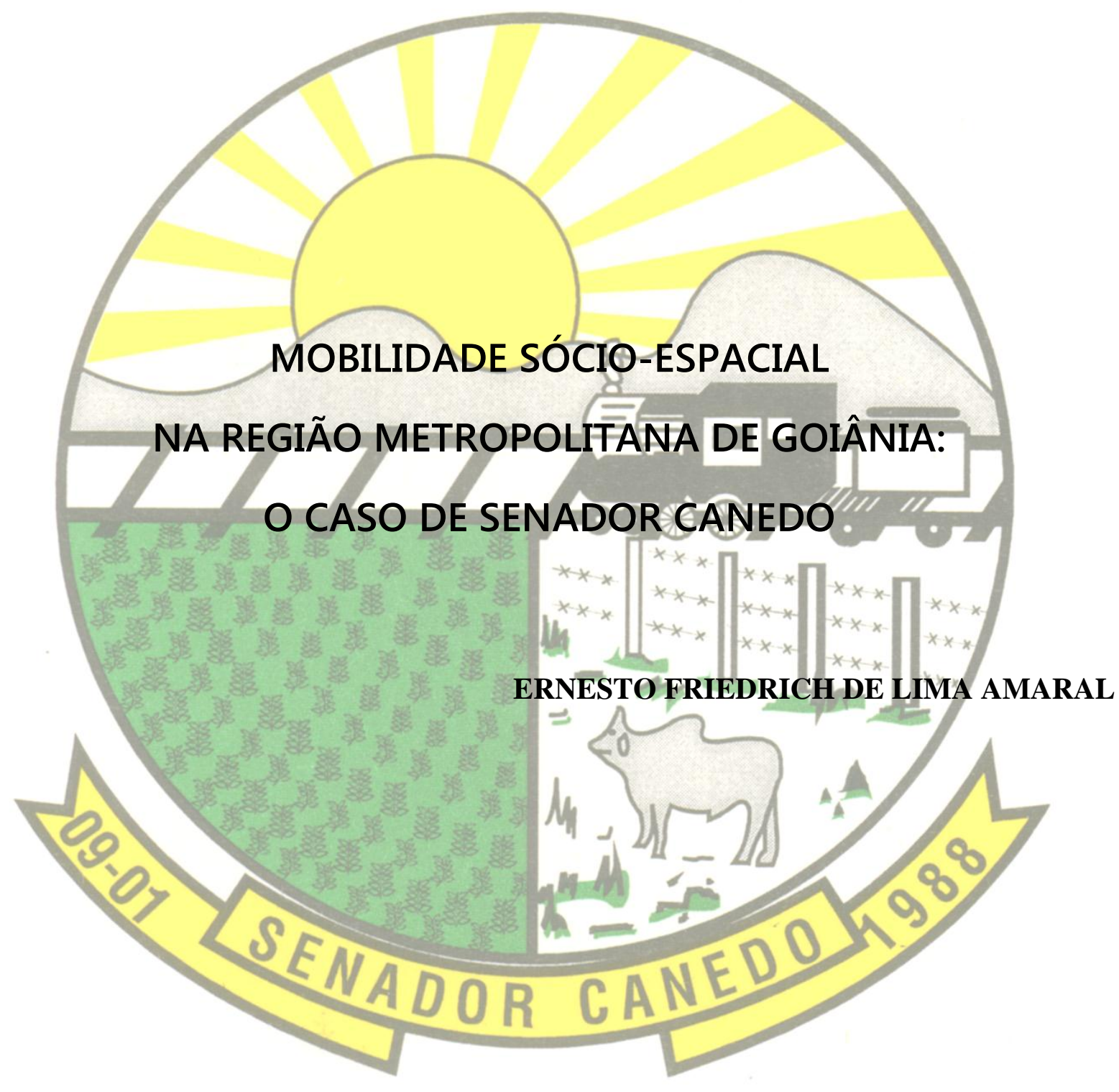

GOIÂNIA 
A ilustração da capa faz parte da bandeira de Senador Canedo. Seu criador é João Alexandre Mendonça Martins, na época com 13 anos de idade e aluno da rede municipal de ensino. São apresentados ícones da cidade, tais como a agropecuária, a estrada de ferro e o morro de Santo Antônio. A data faz referência ao dia da lei de criação do município: 09 de janeiro de 1988. 
ERNESTO FRIEDRICH DE LIMA AMARAL

\section{MOBILIDADE SÓCIO-ESPACIAL NA REGIÃO METROPOLITANA DE GOIÂNIA: O CASO DE SENADOR CANEDO}

Projeto de Pesquisa apresentado como requisito para obtenção do título de Bacharel no Curso de Ciências Sociais, Faculdade de Ciências Humanas e Filosofia, Universidade Federal de Goiás.

Orientador: Prof. Dr. Francisco Chagas Evangelista Rabelo

GOIÂNIA 


\section{AGRADECIMENTOS}

O presente projeto só foi possível ser realizado devido à orientação, colaboração e incentivo do professor e amigo Francisco Chagas Evangelista Rabelo, que desde dezembro de 1997 me transmitiu valiosos conhecimentos das Ciências Sociais, através da experiência em sala de aula e de pesquisas que desenvolvi sob sua orientação.

Lembro ainda todos os professores que, de uma forma ou de outra, contribuíram para minha formação acadêmica durante o transcorrer do curso. Ressalto especialmente os seguintes nomes: Elza Guedes Chaves, Genilda D'Arc Bernardes, Jordão Horta Nunes, Marco Antonio Lazarin, Maria Cristina Teixeira Machado, Maria do Amparo Albuquerque Aguiar, Nei Clara de Lima, Pedro Célio Alves Borges, Robinson de Sá Almeida e Telma Camargo da Silva.

Finalizo destacando a importância de José Reinaldo do Amaral, Lenir Miguel de Lima, Inez Janaina de Lima Amaral e Camilo Vladimir de Lima Amaral, pela sustentação fornecida ao longo da vida.

Aí estão meus sinceros agradecimentos que se concretizam com a elaboração do projeto que se segue. 


\section{SUMÁRIO}

I. INTRODUÇÃO.

III. ABORDAGEM TEÓRICA DO PROBLEMA …............................................ 4

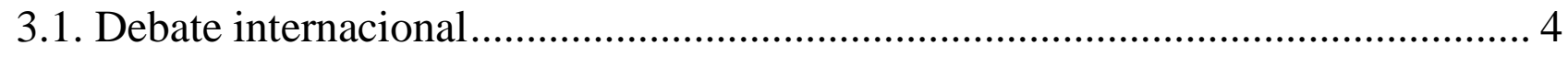

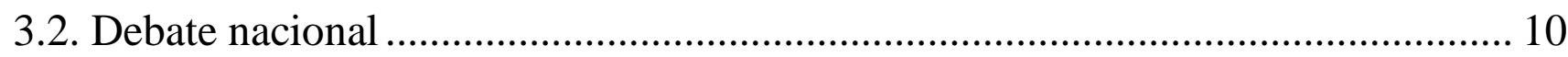

IV. DELIMITAÇÃO DO OBJETO DE ESTUDO …......................................... 17

4.1. A formação do espaço urbano de Goiânia ........................................................... 17

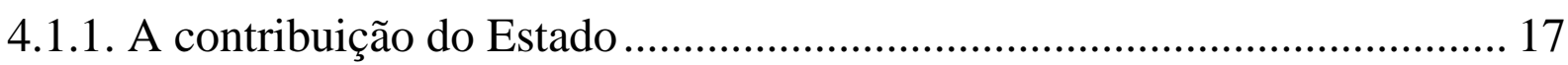

4.1.2. A contribuição do empreendedor imobiliário .............................................. 22

4.1.3. A contribuição dos posseiros urbanos........................................................ 23

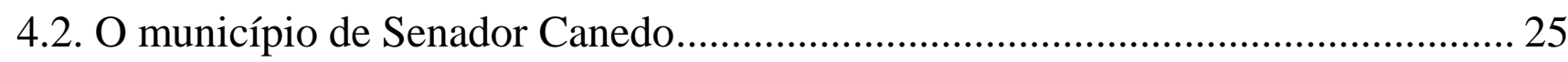

4.3. Objetivação do problema ................................................................................... 31

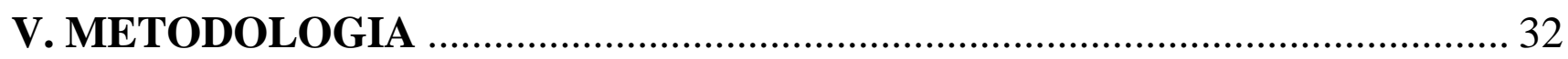

5.1. Mobilidade espacial e estruturação sócio-espacial: construção de um modelo..... 32

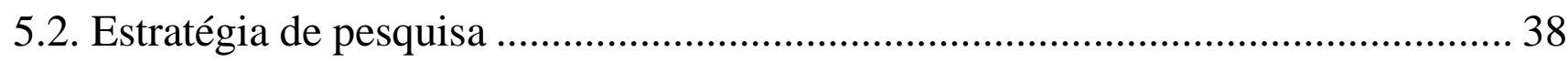

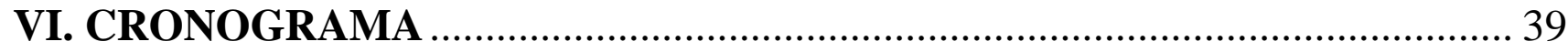

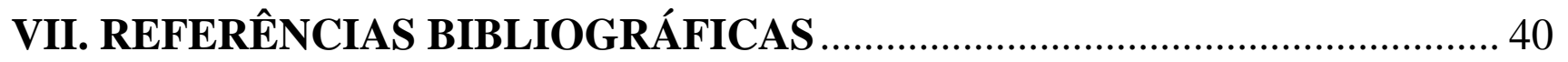




\section{INTRODUÇÃO}

A sociedade brasileira contemporânea vivencia o aprofundamento da crise econômica, ao mesmo tempo que uma reestruturação produtiva e a consolidação de sua inserção no mercado global. Isto faz com que a pobreza urbana se expanda, a economia informal ganhe espaço e o Estado passe por uma profunda crise fiscal. Nesse sentido, é necessário que ocorra um debate com o intuito de avaliar os pressupostos teóricos dos projetos de reforma urbana existentes. O debate, como exposto por Ribeiro (1997), deve ser orientado para a formulação de um novo projeto de reconstrução do espaço urbano, com o predomínio de princípios de gestão democrática, de fortalecimento da regulação pública quanto ao uso do solo urbano e de efetivação de políticas voltadas para as camadas populares.

Esse momento de crise agrava o padrão histórico de estruturação sócio-espacial das metrópoles brasileiras, em termos de centro e periferia, onde vigora a desigualdade social. É importante ressaltar que essa estrutura dual está sendo substituída por uma fragmentação social, uma nova escala espacial de segregação, devido às crises econômica e imobiliária. Observa-se atualmente a segregação de ricos e pobres em enclaves, em espaços fisicamente delimitados, sejam condomínios horizontais ou verticais, sejam ocupações ilegais.

O êxodo rural que antigamente era voltado para as grandes metrópoles, agora se direciona para as cidades de porte médio, conforme argumenta Lago (1998). Goiânia não escapa à essa tendência. Da mesma forma, observa-se um aumento dos fluxos inter-regionais em sua direção. Assim como os principais centros metropolitanos, Goiânia apresenta uma acentuação da segregação social em enclaves, como descrito anteriormente.

O crescimento da cidade de Goiânia há muito ultrapassou os limites municipais, compondo uma mancha urbana que inclui várias cidades e fazendo com que, hoje, nela se inclua o segundo maior município do Estado de Goiás, o município de Aparecida de Goiânia. No todo, Goiânia e seu entorno concentram uma população urbana em torno de 1 milhão e meio de habitantes, cobrindo 15 municípios incluída a capital. Essa expansão urbana fez com que antigos distritos se tornassem municípios autônomos ou bairros, e municípios autônomos se tornassem cidades dormitórios ou, ainda, literalmente, bairros, configurando um processo parecido com aquele observado pelo arquiteto Flávio Vilaça na cidade de São Paulo, de que ela é devoradora de cidades e uma produtora de bairros (VERGARA e ACCORSI, 1999). 
Nas décadas de 70 e 80, a cidade de Goiânia apresentou um crescimento acelerado com todas as características de uma expansão por criação de periferias. Nos últimos tempos, sua dinâmica sócio-espacial adquiriu uma nova configuração, em que ocorre a fusão de vários municípios, na sua mancha urbana. Assim, de uma população de 53.389 habitantes em 1950, a cidade passa a ter, em 1960, 151.013 habitantes. Em 1970, alcança 381.055 habitantes, chegando, em 1980, a 717.526 e a quase um milhão, no início da década, quando então, já se observava a sua expansão para além das fronteiras municipais, o que levava estudiosos e planejadores a pensá-la enquanto aglomerado (CAMPOS e BERNARDES, 1991).

Ao final do século, Goiânia e seu entorno concentram uma população de, aproximadamente, 1,5 milhão de habitantes e o que se afigurava como um aglomerado urbano, toma, agora, a forma conurbada, eliminando-se os vazios urbanos. O que não significa o fim da expansão da periferia, mas a sua redefinição dada pelo surgimento dos enclaves. Provocando o seu deslocamento além dos núcleos urbanos conurbados ou a sua recriação nas fímbrias da cidade-metrópole, como se verifica na região sul de Goiânia, onde se desenvolveram vários bairros sob a influência do processo de ocupação acelerada da capital e completamente inseridos na sua dinâmica.

O crescimento demográfico - decorrente da migração de pessoas de outras Regiões brasileiras -, a fragmentação sócio-espacial e a necessidade da reforma urbana - como prérequisito para democratização da cidade -, fazem da região metropolitana de Goiânia um rico objeto de pesquisa.

Portanto, a pesquisa que pretendo desenvolver concentra-se na análise da mobilidade inter-regional e intra-urbana da região metropolitana de Goiânia, tendo como ponto específico o município de Senador Canedo. Os Censos Demográficos serviriam como principais fontes de dados para o desenvolvimento dessa pesquisa. Semelhantes estudos já foram realizados em outras metrópoles brasileiras, que podem oferecer orientações gerais para o projeto em questão. É o caso dos trabalhos de Bógus, datado de 1987 (apud LAGO, 1998), sobre a metrópole de São Paulo, de Teixeira e Souza (1997) sobre a Região Metropolitana de Belo Horizonte, e de Lago (1998) acerca da cidade do Rio de Janeiro. 


\section{OBJETIVOS}

O presente projeto de pesquisa tem o intuito de estudar a formação e estruturação do município de Senador Canedo, como forma de perceber qual seu papel dentro da região metropolitana de Goiânia. Para isto, será estudado de que modo os deslocamentos populacionais inter-regionais e intra-metropolitanos, em direção àquela cidade, estão afetando a configuração sócio-espacial da região metropolitana. Nesse sentido, avaliando as razões da mobilidade espacial, estar-se-á analisando a influência do espaço urbano e de fatores econômicos e políticos sobre o fluxo populacional, além de compreender de que forma esse fluxo está afetando o espaço metropolitano.

Salienta-se ainda a importância de se realizar um estudo que possa ao menos levantar algumas contribuições para a elaboração de uma proposta de reordenação do espaço urbano, no sentido de democratizar seu uso.

Esse estudo de planejamento urbano e regional poderia ser uma maneira de reforçar a discussão sobre o assunto, suscitando novos e mais amplos trabalhos sobre essa região metropolitana. Portanto, espera-se contribuir para os conhecimentos da Sociologia Urbana, possibilitando, até mesmo, a criação de um centro de pesquisa nessa área. 


\section{ABORDAGEM TEÓRICA DO PROBLEMA}

\subsection{O DEBATE INTERNACIONAL}

Nos últimos anos, a produção científica internacional tem se preocupado com os impactos sociais e espaciais causados pelas transformações econômicas e políticas ocorridas nos países centrais. O foco da questão é a afirmação de que existem relações estruturais entre as transformações em andamento na economia e a intensificação da dualização social. Dualização social é aqui entendida como o alto grau de concentração dos investimentos econômicos e de infra-estrutura básica no núcleo urbano, com uma conseqüente valorização desse espaço. Isso ocasiona a migração da população de menor poder aquisitivo para a periferia, que possui terrenos menos valorizados e uma infra-estrutura precária.

Porém, com a crise do regime fordista, em processo nos últimos trinta anos, constatase alterações no mercado de trabalho, acarretando em transformações sociais. Segundo Lipietz e Leborgne (1988), a crise desse "modelo de desenvolvimento" pode ser assim explicada:

Primeiro, uma crise latente do paradigma industrial, com uma desaceleração da produtividade e um crescimento da relação capital/produto, conduziu a uma queda da lucratividade nos anos 60. A reação dos empresários (via internacionalização da produção) e do Estado (generalização das políticas de austeridade) levou a uma crise do emprego e daí à crise do Estadoprovidência. A internacionalização e a estagnação dos rendimentos detonaram por sua vez a crise "do lado da demanda", no fim dos anos 70 (LIPIETZ e LEBORGNE, 1988, p.16).

Além do problema do desemprego estrutural e da crise do Estado do Bem-Estar Social, observa-se ainda que a inovação em produtos eletro-eletrônicos causa importantes mudanças culturais. Nesse sentido, em razão do surgimento de uma nova configuração sócioespacial das metrópoles, há a necessidade de revisão daquele modelo dual de sociedade. Duas correntes de análise formam-se desse debate: uma que focaliza as mudanças na estrutura social como um todo e outra que se restringe ao estudo da chamada "nova pobreza urbana".

Com a crise do fordismo, a produção industrial passou a ter um papel secundário na economia, com a diminuição das categorias profissionais médias, inclusive a dos operários qualificados. Isso causou a ascensão do setor de serviços, tanto nas categorias profissionais superiores (médicos, advogados, professores) como nas inferiores (empregadas nos serviços de consumo e de escritório). Essa posição é assumida por Sassen ao afirmar que o crescimento da "indústria financeira" foi beneficiado pelas políticas e pelas condições que prejudicaram 
outros setores industriais, principalmente o manufatureiro (SASSEN, 1993, p.200). Isso é tido como ponto de partida para o debate sobre as alterações em curso na estrutura social e a respectiva reestruturação do espaço urbano. Dessa forma, a financeirização da economia global e as transformações tecnológicas acabam provocando a dualização social.

A dualização da estrutura social ocasionaria um impacto na configuração espacial urbana. De um lado, há a apropriação cada vez mais exclusiva dos espaços mais valorizados pelas funções ligadas ao consumo e à moradia de luxo e, de outro, a conformação de espaços exclusivos da pobreza. Daí surgiram expressões como "cidade dual”, "cidade dividida" e "espaço fragmentado", para explicar esse novo padrão de segregação espacial. Porém, há autores que contestam a tese da dualização sócio-espacial, com o argumento de que é uma análise simplificadora, incapaz de explicar a enorme complexidade das sociedades e cidades contemporâneas. De todo modo, a tese de dualidade está baseada na enorme diferenciação social e espacial entre as áreas centrais prósperas e os enclaves com grande concentração de pobreza. Essa abordagem apresenta uma limitação ao não focalizar as práticas e estratégias dos setores sociais médios.

Esses críticos ao modelo dual de sociedade concordam com seu pressuposto: a atual tendência à polarização da estrutura social. A discordância é colocada no momento em que a tese da dualidade social não é capaz de captar a diversidade de grupos sociais e as relações estruturais existentes entre eles no ambiente urbano. Dessa forma, procura-se romper com a idéia de mundos autônomos, independentes, propondo uma leitura que enfatize as relações essenciais entre as divisões sócio-espaciais, através dos diferentes usos que cada um dos grupos sociais faz da cidade.

De um outro lado, a tese da dualização do mercado de trabalho é criticada, pelo fato de que as atividades mais globalizadas representam uma pequena parte do emprego total e de que determinadas ocupações médias sofreram aumento nos anos 80. Um exemplo seria o aumento das categorias médias técnicas qualificadas, com a introdução de tecnologias informatizadas. No comércio, a tendência seria o aumento dos empregados pouco qualificados e mal pagos. Segundo Preteceille, a hipótese da dualização espacial deve ser relativizada, pois é muito esquemático reduzir a questão da segregação à oposição ricos-pobres. Mesmo que haja espaços exclusivos das categorias sociais abastadas, é evidente a diversidade da estrutura social e a complexidade de sua distribuição espacial. Ao lembrar de um estudo do Centre de Sociologie 
Urbaine, este autor afirma que os espaços mais polarizados de Paris somam $42 \%$ do território, mas argumenta:

Esses espaços mais polarizados têm um peso considerável e marcam profundamente a organização da cidade; mas também pode-se dizer que mais da metade, quase $60 \%$ da população, vive em espaços de estrutura social mais complexa. (apud LAGO, 1998, p.9)

Esses estudos evidenciam que grandes áreas socialmente homogêneas tendem a fragmentar-se em micro-espaços excludentes. Dessa forma, acentuou a segregação nos espaços mais burgueses e os espaços operários sofrem o processo de aumento de categorias médias e superiores. Nesse sentido, o foco se refere ao padrão ou escala da segregação atualmente em evidência.

Nesse mesmo debate sobre a relação estrutural entre a dualização do mercado de trabalho e as alterações na estrutura social, Castells (apud LAGO, 1998) desenvolve a tese da polarização social, introduzindo as dimensões política e cultural. Com base num conjunto de estudos sobre Nova York, o autor destaca a grande diversidade sócio-ocupacional presente na cidade, mas observa que a polarização ganha forma no contraste existente entre a capacidade de organização - coesão social - dos altos executivos e a fragmentação dos grupos sociais restantes, em função de etnia, gênero e ocupação. Como conseqüência, temos uma elite que atua em conjunto com o poder público local nos grandes projetos de reestruturação urbana na área central, aprofundando a segregação espacial vigente. Podemos dizer que, a partir da perspectiva espacial, a metrópole moderna é ao mesmo tempo "crescentemente dual e crescentemente plural". A introdução da dimensão política na análise da estrutura sócio-espacial feita por Castells relativiza, assim, o papel da reestruturação produtiva como fator determinante das mudanças sociais em curso, resgatando para o debate as alterações nas funções do Estado (redução do Estado do Bem-Estar) e, fundamentalmente, a redução do poder de organização da classe trabalhadora (enfraquecimento dos sindicatos) como condições para que o novo regime de acumulação possa se impor.

A outra vertente de análise sobre os efeitos sócio-espaciais da reestruturação econômica centra-se na emergência da chamada nova pobreza urbana. A pobreza, que no período fordista era vista como resíduo do passado, volta a ocupar um lugar central nas ciências sociais e nos estudos urbanos. A nova pobreza, por sua vez, guarda estreita relação com a tese da dualização social, na medida em que esse novo segmento se constitui numa das pontas das socie- 
dades crescentemente polarizadas e marcadas não apenas pela desigualdade, mas pela exclusão de parte de seus membros do mundo do trabalho e das redes de sociabilidade vigentes.

A noção de exclusão social ou nova pobreza está relacionada à reestruturação produtiva e à conseqüente retração dos empregos, que teriam instituído uma nova divisão social do trabalho, marcada pelos inseridos e pelos não inseridos no sistema produtivo hegemônico. A nova pobreza relaciona-se também com o enfraquecimento do poder organizativo dos trabalhadores, a crescente mobilidade espacial deles e a crise das instituições públicas, que teriam criado as condições para a ruptura das redes de sociabilidade.

Quanto à dimensão geográfica, a concentração de pobres num determinado espaço geográfico é um dos fatores impeditivos de saída da condição de pobreza e de exclusão. Nesse sentido, o confinamento espacial reproduz o isolamento social, perpetuando o círculo vicioso da pobreza. Nessa formulação, há um resgate dos princípios ecológicos da segregação social urbana, mesmo que fatores estruturais estejam no centro da explicação da emergência da subclasse urbana.

Por fim, convém chamar a atenção para a dimensão temporal presente na conceituação da nova pobreza urbana. A especificidade da nova pobreza na sociedade pós-fordista é seu caráter irreversível e crônico; é a ausência de expectativas de inserção ou ascensão social que marcaram a dinâmica social e urbana no modelo econômico anterior.

Uma outra perspectiva analítica tem abordado a relação entre reestruturação econômica e mudanças espaciais, privilegiando o papel do capital imobiliário no atual quadro de supremacia do setor financeiro. A emergência de um novo padrão de segregação urbana é analisada não mais sob a perspectiva das transformações na estrutura sócio-ocupacional, e sim a partir da lógica de atuação da atividade de construção civil.

Há uma mudança estrutural no sistema econômico, a partir dos anos 80, com a transferência dos investimentos de capital das atividades produtivas para os setores financeiro e imobiliário. A recomposição do ambiente construído urbano e sua relação com as novas atividades econômicas e sociais deveriam ser analisadas à luz dessa tendência. O que sustenta a tese da transferência de capital para a atividade imobiliária é a evidência empírica de que o montante de novas construções não tem relação direta com a demanda efetiva por parte dos consumidores e produtores. Nesse sentido, essa ação do capital imobiliário não deve ser entendida com simples resposta ao crescimento do setor terciário moderno e de categorias profissionais correspondentes. Portanto, é de extrema relevância analisar a origem e a forma como 
vem ocorrendo o afluxo de capital para o setor imobiliário. O grau de atratividade das cidades quanto ao afluxo de investimentos externos é outro fator que vem orientando a lógica da produção do ambiente construído urbano. Na competição intercidades, os governos locais, em parceria com o setor imobiliário/financeiro, passam a priorizar políticas de renovação urbana visando ao crescimento econômico, em detrimento das políticas de bem-estar social.

Um novo modelo de diferenciação sócio-espacial nas grandes cidades, marcado pela segregação excludente ou mesmo pelos enclaves é o resultado dessa nova racionalidade subjacente aos grandes empreendimentos urbanos/imobiliários. O processo de gentrification nas áreas centrais é uma das expressões dessa nova racionalidade e diz respeito: ao sobrelucro gerado e apropriado pelo setor imobiliário através da alteração do padrão de uso do solo existente no centro; à criação de um novo padrão de consumo para os novos setores médios profissionais, que engloba moradia, lazer e comércio; e, ao deslocamento da classe operária para os subúrbios e periferias urbanas. É interessante observar que o novo modelo de segregação espacial não tende a excluir completamente os trabalhadores manuais ou de serviços de baixa qualificação do núcleo urbano.

Na mesma direção, caminha a análise de Gottdiener sobre as mudanças no padrão sócio-espacial das metrópoles americanas, para a qual o autor desenvolve amplamente a fundamentação teórico-metodológica.

Em essência, os marxistas tendem a interpretar economicamente as mudanças sócio-espaciais - como se fossem causadas por mudanças na localização de empregos e indústria. Quanto a mim, considero as mudanças um resultado dialético de fatores políticos, culturais e econômicos que se manifestam através da linha de frente dos padrões de desenvolvimento imobiliário que congregam a intervenção do Estado, formas de acumulação de capital e a manipulação dos mercados de terra. (...) Mais significativamente, a asserção discutida aqui é que a articulação entre intervenção do Estado e circuito secundário de capital constitui o motivo principal das mudanças sócio-espaciais, embora não seja a única causa delas (GOTTDIENER, 1997, p.235236).

Na realidade, a produção do espaço construído é vista como um processo de caráter anárquico, em que a desigualdade sócio-espacial é resultado da forma qualitativamente diferente pela qual as frações de capital, em conjunção com o Estado, se apropriam do espaço. O foco de sua análise está no papel central do setor imobiliário na reprodução do capital em geral e das redes público-privadas organizadas em torno desse setor. A competição entre empreendedores que pressionam o setor imobiliário a superproduzir é estimulada pela disponibilidade geral de capital nesse setor. Os fenômenos da suburbanização e da renovação urbana nas áreas centrais das metrópoles são analisados sob essa ótica. O padrão espacial resultante ca- 
racteriza-se pela cidade fragmentada em espaços residenciais e comerciais exclusivos. A metrópole de Los Angeles é o produto mais acabado dessa nova organização do espaço suburbano que tem perpetuado a contínua expansão das cidades periféricas através de megaempreendimentos residenciais e comerciais. O padrão monocêntrico da cidade industrial deu lugar à metrópole dispersa e policêntrica, com baixa densidade populacional e profundamente segregada

Com as abordagens até aqui apresentadas, procurei traçar um quadro geral de referência dos modelos analíticos que têm sido utilizados nos estudos sobre reestruturação sócioespacial nas metrópoles do mundo desenvolvido. Conceitos como dualização social, exclusão e fragmentação espacial, presentes em grande parte da literatura voltada para os efeitos sociais e espaciais da crise econômica, indicam mudanças profundas nas sociedades contemporâneas e, como instrumentos político-ideológicos, assumem a função de denunciar os resultados negativos gerados pela transformação do padrão de acumulação. Mesmo que a noção de dualidade seja reducionista e esconda o grau de complexidade da estrutura social nos países centrais, não há dúvida sobre a crescente precarização das relações de trabalho e das condições de reprodução de parte significativa da classe trabalhadora. As mudanças na configuração espacial dos grandes centros expressam não apenas esse novo quadro social mas as especificidades da dinâmica urbana-imobiliária e o papel do capital incorporador na nova ordem econômica.

Como se trata de um quadro teórico de referência para o desenvolvimento de um estudo sobre uma metrópole latino-americana, é hora de questionar a validade desses conceitos e abordagens. Em que medida as noções de dualização social e exclusão indicam novas tendências num país, ou num continente, onde a acumulação e o crescimento econômico foram sustentados por uma crescente taxa de exploração do trabalho e por um exército industrial de reserva de enorme vulto? Em que medida a segregação espacial excludente evoca algo de novo nas metrópoles brasileiras, marcadas historicamente por profundas desigualdades espaciais entre o núcleo urbano e suas periferias? 


\subsection{O DEBATE NACIONAL}

Os estudos recentes sobre as cidades latino-americanas têm como unidade o estabelecimento de conexões entre a crise econômica e as políticas recessivas, por um lado, e as mudanças no padrão de urbanização, por outro. Tenta-se avaliar os efeitos negativos da estratégia defensiva de ajuste nas áreas metropolitanas, num quadro de recessão prolongada, de crise do setor público e, conseqüentemente, de acúmulo de desigualdades sociais. Crise econômica é aqui entendida sob a mesma perspectiva de Lipietz e Leborgne (1988), qual seja, “crise latente do paradigma industrial”, como citado à página 05. Nesse sentido, as mudanças sócioeconômicas em curso não têm um caráter meramente conjuntural, mas sim, apresentam o surgimento do desemprego estrutural e da crise do Estado do Bem-Estar Social.

Uma primeira evidência é o relativo esvaziamento econômico e a redução das taxas de concentração populacional nas grandes metrópoles, redirecionando o processo de expansão urbana para as cidades de porte médio. É interessante observar que as análises sobre a reestruturação espacial nos países latino-americanos estão centradas nos impactos da crise econômica sobre a pobreza urbana, seja esta considerada através do nível de renda da população, das condições de emprego ou das condições urbanas de vida. Subemprego, concentração de renda e precarização das relações de trabalho são indicadores utilizados na compreensão do fenômeno da pauperização da maioria da população latino-americana e em sua relação com as novas configurações espaciais das cidades. Vejamos, no caso do Brasil especificamente, como a literatura tem abordado o tema.

As análises dos novos padrões de segregação sócio-espacial tomaram como ponto de partida o quadro de crise econômica e social que marcou os anos 80, no país. Estudos sobre a conjuntura social brasileira subsidiaram as correlações entre as mudanças macroestruturais e os processos sócio-espaciais localizados. Duas dessas mudanças atingiram, direta ou indiretamente, a dinâmica das grandes metrópoles brasileiras. A primeira foi o deslocamento da economia para o setor exportador. Áreas agrícolas modernas se expandem no interior de São Paulo e no Centro-Oeste, alterando a configuração espacial do território brasileiro, marcada até então pela primazia das grandes metrópoles. Portanto, os incentivos ao setor agroexportador aprofundaram os efeitos da crise.

A segunda mudança estrutural foi a significativa elevação da participação do setor financeiro na economia, que gerou repercussões diretas na dinâmica urbana/imobiliária a par- 
tir tanto do acelerado aumento da demanda por imóveis comerciais dirigidos a esse setor e aos demais serviços a ele vinculados quanto da criação dos fundos de pensão, responsáveis pela construção de shopping centers e edifícios de escritórios nos grandes centros do país. Os efeitos da crise sobre as condições de reprodução social foram dramáticos: precarização das relações de trabalho com redução da estabilidade do emprego e da renda; achatamento salarial e redução do poder de compra da classe trabalhadora; inversão da tendência à diminuição do número relativo de pobres e aumento das desigualdades de renda.

Os fenômenos da pauperização da população brasileira e da informalização do trabalho foram os subsídios empíricos para que a noção de exclusão social caísse no domínio público. A noção de exclusão passou a ser conceitualmente vaga, apresentando duas questões centrais. A primeira diz respeito à especificidade ou à novidade do que se classifica hoje como exclusão. No Brasil, pode-se dizer que exclusão lato sensu sempre houve, mas essa afirmação não captaria a especificidade do que contemporaneamente chamamos exclusão. Nesse caso, a questão se constrói na comparação com os países desenvolvidos, onde o conceito de exclusão social foi definido no âmbito da crise de um modelo econômico com ampla capacidade de integração social e do colapso de um padrão de regulação que garantia ganhos sociais reais à classe trabalhadora.

A segunda questão é colocada frente ao problema da população miserável que se forma atualmente, constituindo mesmo uma classe perigosa, pertencente a outro mundo. Ou seja, há a construção de uma visão de dois mundos - dos incluídos e dos excluídos. A expansão do capitalismo no país se deu com base na crescente distância entre produtividade e custo da reprodução dos trabalhadores, o que não gerou uma crise de realização do capital graças à emergência dos novos setores sociais médios que garantiram a demanda para o mercado de bens duráveis. Na visão antidualista, de cunho marxista, as altas taxas de exploração eram garantidas pelo baixo grau organizativo da classe trabalhadora e pela existência de um amplo exército industrial de reserva, que, além de enfraquecer o poder de barganha dos incluídos por melhores salários, era responsável pela produção informal de bens e serviços de baixo valor, mantendo o custo da reprodução da força de trabalho reduzido.

Nos anos 70 e 80, foi dominante na literatura crítica sobre a questão urbana a idéia da dualização do ambiente construído urbano para qualificar o padrão de organização espacial das metrópoles brasileiras, a partir dos anos 50. Em um pólo, a segregação da população pobre nas precárias periferias, possibilitando-lhe amplo acesso à moradia através da produção 
extensiva de loteamentos populares e, no outro, a expansão nas áreas centrais da forma empresarial de produção residencial que se consolidou nos anos 70 com o advento do Sistema Financeiro de Habitação. A noção de padrão periférico de urbanização passou a ser utilizada, a partir da década de 70, para explicar a particularidade da metropolização brasileira, resultante da combinação entre a modernização da economia, com o consequiente aumento da produtividade, e as formas extremas de exploração da classe trabalhadora. Nesse modelo de crescimento, estabeleceu-se, via intervenção do Estado, um crescimento urbano segregador e excludente. De um lado, porque a lógica das políticas públicas era atender prioritariamente às necessidades do grande capital em matéria de infra-estrutura e serviços urbanos, relegando a plano secundário as relativas à reprodução da força de trabalho. De outro, a inadimplência do poder público quanto ao controle e ordenamento do crescimento urbano permitiu que o espaço das grandes cidades fosse organizado ao sabor da especulação imobiliária, encarecendo enorme e artificialmente o preço da terra. A tolerância com a cidade ilegal garantiu, por sua vez, a integração na sociedade urbana dos segmentos populares necessários à acumulação.

No Rio de Janeiro, a análise do processo de segregação social foi o centro das preocupações de várias pesquisas sobre a estrutura interna do espaço metropolitano. Foi construído um modelo analítico que percebia o novo modo de urbanização caracterizado pelo fato de aos pobres ser cada vez mais vedado e controlado o acesso à moradia nos núcleos. Esse estudo foi elaborado por Brasileiro (apud LAGO, 1998), ao estudar o Rio de Janeiro, dividindo-o em núcleo e periferias imediata, intermediária e distante.

Na explicação do processo de estruturação urbana, podemos identificar duas vertentes: uma que atribui a segregação residencial à conjugação dos efeitos do mercado fundiário e da intervenção do Estado e outra que busca entender a dinâmica metropolitana a partir da própria periferia, da sua lógica de organização. Sob a ótica da primeira vertente, segundo Vetter e Massena (apud LAGO, 1998), a segregação residencial seria decorrente de um mecanismo que tenderia a aumentar sempre as rendas monetária e real dos estratos superiores da sociedade e, contrariamente, a diminuir as dos inferiores. A desigual distribuição espacial dos investimentos públicos em infra-estrutura e equipamentos coletivos, consequiência da maior capacidade política das camadas superiores, é considerada o fundamento desse mecanismo. Introduzindo a perspectiva histórica, Abreu e Bronstein (apud LAGO, 1998) avaliaram o papel das políticas urbanas na segregação dos pobres e consolidaram a noção de padrão periférico ao 
apresentarem uma explicação do processo de segregação residencial para além dos efeitos da conjuntura político-econômica.

Os trabalhos referentes à segunda vertente centram-se na lógica de organização do espaço periférico a partir da análise dos processos de loteamentos populares, na qual se procurava demostrar a existência da espoliação dos compradores e a informalidade das operações econômicas. A relação entre os agentes envolvidos na produção dos loteamentos era o objeto central das análises, com ênfase nas estratégias especulativas dos loteadores/proprietários de terra e na omissão do poder público quanto ao controle do uso do solo e à política de investimentos. A periferia era compreendida como o espaço dos loteamentos e da autoconstrução da moradia em contraposição ao espaço da produção habitacional empresarial alocada no núcleo, o que reafirmava o modelo analítico dual núcleo-periferia.

Em síntese, cabe destacar cinco elementos analíticos que fundamentaram o modelo núcleo-periferia na explicação da dinâmica da organização espacial metropolitana: o par centro/periferia, de noção operatória de pesquisa, tornou-se um modelo utilizado para entender o processo de estruturação interna das metrópoles; o termo periferização se refere a um processo de segregação e diferenciação social no espaço que tem causas econômicas, políticas e culturais; consolidou-se, como inerente ao padrão periférico, a representação da periferia como espaço da reprodução precária da força de trabalho ou espaço de carência, portanto socialmente homogêneo; a dinâmica de crescimento periférico era entendida como a projeção, no nível do espaço, do processo de acumulação ou como representação da hierarquia social vigente na sociedade brasileira; e, a intervenção seletiva do Estado na alocação dos investimentos urbanos era tomada como mecanismo central do padrão de estruturação urbana, assim como a ação dos agentes dos mercados fundiário e imobiliário e suas respectivas práticas.

No modelo dual núcleo-periferia, o processo de favelização nas áreas centrais era incorporado como um fenômeno residual frente à expansão periférica. As favelas, portanto, não rompiam com a dualidade espacial. Foi na década de 70 que a favela passou a ser vista como resultado das transformações sociais que acompanharam o padrão de industrialização brasileiro, responsável pelo intenso crescimento demográfico dos centros urbanos do Sudeste via migrações campo-cidade. Assim, o processo de favelização seria uma das expressões do padrão de urbanização excludente e desigual que se desenvolveu no país.

Uma visão bastante difundida nos anos 70 era de que a favela seria a primeira alternativa de moradia do migrante recém-chegado, que, ao alcançar uma certa estabilidade no traba- 
lho, passaria para a "segunda etapa" do seu percurso de ascensão social tornando-se proprietário de um lote na periferia. O princípio ecológico da segregação espacial do migrante nas zonas centrais e sua posterior mobilidade social e espacial ascendente orientava boa parte das análises sobre favelas. Alguns estudos, entretanto, demonstraram que para muitos trabalhadores a favela era o fim e não o início de uma trajetória no interior da metrópole. Os favelados constituíam um grupo cujos níveis de vida se situavam abaixo dos padrões de subsistência prevalentes no conjunto da classe trabalhadora brasileira.

Assim como a periferia, a favela era compreendida como um universo socialmente homogêneo composto de pobres, em sua maioria migrantes sem qualificação para o trabalho. Foram poucos os estudos que avaliaram o grau de heterogeneidade da população favelada. Parisse (apud LAGO, 1998) foi pioneiro nesse tipo de abordagem, ao traçar o perfil sócioeconômico dessa população com base nos dados censitários de 1950 e chegar à conclusão de que "a favela abrange um modo complexo, heterogêneo, descontínuo". Para Castro (apud LAGO, 1998), era possível distinguir em 1970 favelas cariocas com conteúdos sociais bastante diferenciados. As localizadas na zona suburbana se assemelhavam a bairros operários devido ao número significativo de trabalhadores da indústria de transformação, enquanto as demais se caracterizavam como bairros populares cujos moradores apresentavam um perfil ocupacional mais diversificado, ligado predominantemente aos setores de serviço e comércio.

Outra vertente, no estudo sobre a favela, deteve-se na análise da evolução da política estatal com relação a essas áreas, instituindo o debate remoção x urbanização. Por trás desse debate constituíu-se o argumento contra a remoção, baseado na idéia da integração do favelado à cidade e da favela como estratégia de inserção dos pobres no mercado de trabalho. A localização privilegiada das favelas nas áreas centrais garantia a proximidade entre trabalho e moradia. A favela estava cercada de cidade por todos os lados, com os favelados trabalhando próximo, com seus filhos freqüentando escolas públicas do bairro, com todos os sinais de uma integração constante. A periferia já está isolada, já foi posta direta ou indiretamente à margem. A marginalidade dos seus habitantes é o resultado de ações conscientes executadas com a finalidade de separar e de definir as fronteiras dentro da cidade.

A erradicação de vários assentamentos nessas áreas centrais de alta densidade, somada à explosão demográfica das periferias, levaram alguns estudiosos a preverem, no final dos anos 70, o desaparecimento das favelas do cenário urbano carioca. Se, por um lado, a previsão 
não se confirmou, por outro, os estudos sobre as desigualdades sócio-espaciais nas grande metrópoles abandonaram a preocupação com as favelas em favor das periferias.

Também sob a perspectiva da dualização do espaço urbano, alguns estudos foram desenvolvidos, já nos anos 80, com o objetivo de analisar o novo padrão empresarial de produção do ambiente construído no núcleo, que se consolidou com o advento do Sistema Financeiro de Habitação - SFH, a partir da década de 60. Nesse período, a lógica da acumulação urbana afirmou-se nas Cidades do Rio de Janeiro e de São Paulo e se expandiu por várias capitais, através da atuação das grandes empresas incorporadoras que passaram a controlar uma grande fatia do mercado imobiliário, até então dominado pelo pequeno especulador. O que é importante destacar dessa linha de análise é a compreensão da dinâmica de organização do espaço urbano que ela introduz, a saber: a lógica da acumulação urbana se assenta num modo de produção do ambiente construído que reproduz permanentemente as desigualdades materiais e simbólicas do espaço. A ação dos agentes imobiliários se baseia na constante transformação da divisão sócio-espacial, produzindo a obsolescência de determinados espaços e abrindo novas fronteiras de valorização através de áreas antigas ou da abertura de novos espaços de urbanização.

Segundo esse tipo de abordagem, é o setor capitalista que estrutura os padrões de valorização e as formas de uso do solo na cidade, embora sua produção seja relativamente pequena em termos quantitativos e se concentre no núcleo urbano. Em muitas capitais a moderna produção capitalista foi praticamente criada pela intervenção estatal, através da política de construção de moradias populares e da instituição do Sistema Financeiro de Habitação. Nesse contexto, o papel do Estado na organização do espaço urbano vai além da regulação pública da urbanização e das políticas de investimento em infra-estrutura de serviços. De um lado, há análises de uma macro-interpretação em relação a esse setor capitalista, apontando sua função política na construção da aliança entre o capital internacional, o capital local e o Estado. De outro, há uma avaliação crítica que propõe relacionar os determinantes macroestruturais com as contradições especulativas da reprodução do capital imobiliário.

Voltemos à idéia hoje corrente na literatura de que a crise econômica e social mais geral e as alterações da dinâmica interna nas grandes cidades brasileiras, que marcaram a última década, resultaram na transformação do padrão de segregação social.

Uma série de estudos demográficos tem apontado uma inflexão no processo de concentração populacional nas grandes metrópoles brasileiras e o simultâneo fortalecimento das 
cidades médias, a partir do redirecionamento dos fluxos migratórios para áreas mais promissoras quanto a oferta de emprego. Na década de 80, a periferia dos grandes centros passa a receber, predominantemente, população deslocada da própria metrópole, diminuindo assim o ímpeto de seu crescimento.

Há estudos que apontam para uma diminuição da segregação, com base no fato de a população pobre ser obrigada a procurar moradia em locais mais centrais, próxima aos centros residenciais e de atividades que favoreçam a inserção num mercado de trabalho instável e de baixa remuneração. Tal empobrecimento das áreas centrais valorizadas é acompanhado pelo surgimento de novas modalidades de segregação, que excluem o pobre não só pelo alto preço cobrado pelo acesso, mas também pelos sofisticados sistemas de segurança privada.

Alguns autores defendem que as transformações do espaço urbano, na última década, não seriam apenas efeito de um ciclo de estagnação econômica, mas de alterações na dinâmica da produção imobiliária. Por um lado, o padrão periférico de crescimento metropolitano, que prevalecia desde os anos 50, estaria em esgotamento pelo duplo movimento de crise e modernização das esferas de produção e de circulação do espaço construído. Por outro, o crescimento na produção de imóveis não-residenciais, resultante sobretudo da multiplicação de empresas financeiras, expressa as mudanças em curso no setor imobiliário empresarial. A conseqüência é a emergência de novas formas de incorporação imobiliária que inovam e modernizam as cidades, ao mesmo tempo que acentuam a segregação social.

As novas evidências sócio-espaciais exigem uma maior complexidade do modelo dual de estruturação urbana. Como nas cidades dos países centrais, um padrão de segregação excludente se instaura nas metrópoles brasileiras através da formação de enclaves por todo o tecido urbano, tanto de ricos quanto de pobres. Permanece, entretanto, a discussão sobre a validade dos modelos analíticos até então utilizados na compreensão dos processos espaciais. 


\section{DELIMITAÇÃO DO OBJETO DE ESTUDO}

\subsection{A FORMAÇÃO DO ESPAÇO URBANO DE GOIÂNIA}

A formação do espaço urbano de Goiânia a partir de 1975, resulta de dois grandes processos: do adensamento exagerado e pontual de alguns bairros e da dispersão exagerada da periferia. Três agentes assumem papel de destaque na ocupação do solo urbano. O Estado age sobre o espaço urbano através de dois instrumentos básicos: os investimentos públicos e a normatização legal. Os empreendedores imobiliários, historicamente aliados ao Estado, adotam estratégias racionalizadoras visando ampliar o seu mercado consumidor. Com o objetivo de maximizar suas taxas de lucros, em alguns casos acabam impondo ao Estado alterações no aparato normativo em vigor. Finalmente, os chamados invasores ou posseiros urbanos, que pressionados pela necessidade de morar de forma organizada, forçam a ocupação dos espaços vazios. A análise desses processos está baseada nos trabalhos de Chaves (1985), Campos e Bernardes (1991) e Arantes (1992).

\subsubsection{A CONTRIBUIÇÃO DO ESTADO}

Em 1975, o plano do Governo Estadual contemplava, como ação no espaço da cidade, o direcionamento da expansão urbana na direção leste-sudoeste. Para atingir este objetivo, o Governo Estadual propôs mecanismos de zoneamento, sistema viário, transporte, aplicação da lei de loteamento, obras físicas do órgão de planejamento, obras de infra-estrutura e definição de uma política de uso do solo para induzir modificações estruturais.

No Governo Municipal, o plano de ação previu como objetivos, a melhoria da qualidade do meio ambiente, a ampliação das oportunidades de desenvolvimento individual e social, a ampliação das oportunidades de recreação e lazer, ampliação das oportunidades de habitação e a promoção de uma interação de Goiânia com sua região de influência. As principais ações visavam atingir o objetivo geral de dotar a cidade de um sistema de transporte, com intervenções no sistema viário, através de convênios com os Governos Estadual e Federal para a obtenção de recursos.

Em outubro de 1975, a Câmara Municipal aprovou um anteprojeto que estabeleceu a estrutura viária articulada ao zoneamento, já antevendo as propostas para o Sistema de Trans- 
porte; transformou o Escritório de Planejamento em uma autarquia denominada Instituto de Planejamento Municipal - IPLAN; e estabeleceu uma nova legislação de zoneamento e uso do solo. Em novembro deste ano foi apresentado o Plano de Implementação do Sistema Integrado de Transporte de Massa de Goiânia. Este plano propunha a criação da Empresa de Transportes Urbanos de Goiás -TRANSURB, que seria concessionária da Prefeitura para o planejamento, implantação e administração dos transportes em Goiânia por um período de 30 anos, ou seja, até o ano 2006.

Em dezembro deste mesmo ano foi apresentado o Plano de Recreação, que propunha preservar as áreas verdes, criar espaços organizados de recreação, revitalizar os setores tradicionais da área central, Campinas e Praça Universitária, além de reciclar os edifícios pioneiros da cidade, como a Câmara Municipal, Cine Teatro Goiânia, Grande Hotel, edificações históricas de Campinas, Museu e Estádio Olímpico Pedro Ludovico. Propunha, ainda, a animação da Cidade, a descentralização da cultura, o desenvolvimento das artes e da criatividade, e o incentivo à cultura popular. A criação do Instituto de Desenvolvimento Urbano e Regional INDUR, no final de 1975, concluiu a preparação para a ação do Estado.

O INDUR conveniado com o IPLAN constituiu três grupos de trabalho para estudar e propor soluções para a expansão urbana, para o sistema de circulação e transporte e para o sistema de áreas verdes e recreação. Estes trabalhos, oriundos dos estudos iniciados por estes grupos, iriam resultar em documentos publicados no fim da década e influenciar os planos e ações da gestão seguinte, na primeira metade dos anos 80 .

Já em 1976, foram desenvolvidos os projetos de infra-estrutura viária do "Sistema de Transporte de Massa de Goiânia" e iniciadas as obras de pavimentação que, planejadas inicialmente em $80 \mathrm{Km}$ de vias, chegaram a atingir $105 \mathrm{Km}$, ficando ainda incompleta a infraestrutura proposta no Sistema Viário Básico. Goiânia, que possuía somente $40 \%$ da área urbana pavimentada, situada na faixa central mais densa, entre o Setor Central e Campinas e abrangendo os bairros limítrofes ao centro, como Vila Nova, Setor dos Funcionários, Fama, Vila Operária, Setor Coimbra e Setor Leste Universitário, assistiu à pavimentação de uma centena de quilômetros em apenas dez meses.

Este plano de obras de pavimentação possuía uma diferença dos anteriores: deixava para trás os bairros mais adensados e próximos ao centro e avançava pelas chamadas "vias coletoras", em direção à periferia mais longínqua. As vias atingiam praticamente todos os bairros de Goiânia. A maior parte (90\%) deste Plano de Pavimentação se deu ao sul da Av. 
Anhanguera, porque a região norte era mais pobre e mais densa, com menos áreas vazias, como resultado do abandono por que vinha passando nas últimas décadas.

Essa pavimentação foi um grande estimulo à expansão da região sul. Os terrenos junto às vias recém-pavimentadas atingiram elevados preços, devido à sua valorização. Foram integrados cerca de 195 bairros ao "Sistema de Transporte Integrado de Massa", dos quais doze já no município de Aparecida de Goiânia.

Em junho de 1979, assume um novo prefeito, que inicia sua gestão sob o argumento do planejamento. Em 75 dias, apresenta para o debate público suas "Diretrizes" do Governo Municipal. Este documento preliminar fixava algumas políticas para administrar a cidade: meio ambiente natural e construído, serviços públicos, transportes, lazer, esportes, bem-estar social, política financeira e fiscal de apoio às atividades econômicas, e participação pública. Logo depois, foi elaborado o plano "Diretrizes Básicas para o Planejamento", que partiu dos estudos desenvolvidos pelo INDUR sobre a expansão urbana.

A expansão ao sul pelos loteamentos de Aparecida de Goiânia e a incipiente implantação de depósitos, comércios atacadistas e indústrias ao norte, ao longo da via Perimetral Norte, estabeleceram a implantação de corredores de transporte nos sentidos norte-sul e lesteoeste. Muitos outros projetos foram feitos, em todas as áreas, mas poucos se concretizaram. Não foi viabilizada a expansão à oeste, proposto para várias classes de renda. Não se implantaram ou se desenvolveram os eixos da Perimetral Norte, córregos Botafogo e Cascavel. O uso do solo, por sua vez, não aconteceu ao longo destes eixos.

No final da década de 70, os adensamentos populacionais ocorreram nos bairros mais ricos, principalmente no Setor Oeste, junto ao centro, e no Setor Bueno, no extremo sul do município. O eixo T-63 foi alargado, alcançando uma certa ocupação do uso do solo ao longo de toda via, especialmente chamando a atenção para as dezenas de prédios de apartamentos construídos no Setor Bueno. O processo de ocupação do solo, criando lugares com grande intensidade de uso, se intensificou, assim como a ocupação rarefeita e extensiva dos loteamentos ao sul, que já atingiam então o município após Aparecida de Goiânia, o de Hidrolândia.

A partir das eleições em 82 e a posse em março de 83 , mudou o quadro políticoideológico e tanto o Governo Estadual, quanto o Municipal abandonaram a postura dos planos intra-urbanos, até então adotados, em favor de obras de impacto, com grande apelo populista e de visibilidade. 
Projetos como a Vila Mutirão, onde se construiu, num único dia, mil casas, contou com a participação de empresas imobiliárias no campo da construção civil, para a produção das peças pré-fabricadas, que foram montadas em cima de um arruamento pré-definido, com os lotes demarcados e preparados para receber a casa pré-moldada. A qualidade e os custos finais destas habitações, além da localização na zona rural, à beira da rodovia GO-070, foram os aspectos mais criticados.

A exemplo do que começou a acontecer em todo o país, um discurso de participação popular nas decisões articulou um planejamento implícito e ideológico de obras com a participação intensa dos empreendedores imobiliários, principalmente daqueles vinculados a obras públicas. Novas tendências apareceram, no entanto, face ao número cada vez maior da população excluída socialmente.

A proposta de construção de equipamentos de educação e saúde, somadas as já existentes de infra-estrutura viária, transporte coletivo e uso do solo, compuseram a nova estratégia do Estado para a formação do espaço urbano. Grandes recursos foram mobilizados para a produção de um novo Plano de Desenvolvimento Integrado de Goiânia, abrindo-se com isso um novo horizonte para o exercício do planejamento de Goiânia, tendo em vista possíveis avanços na democracia da gestão da cidade.

Quanto à contribuição do Poder Público Municipal e Estadual na formação do espaço urbano de Goiânia, é necessário destacar dois instrumentos fundamentais para o ordenamento espacial da cidade. $\mathrm{O}$ primeiro se refere à reestruturação do órgão central de planejamento, e o segundo, à definição das Políticas de Desenvolvimento para o Município. Pode-se dizer que tanto o governo municipal quanto o estadual, a partir de 1983, na perspectiva de que estavam iniciando uma nova fase na administração pública, procuraram se instrumentalizar institucionalmente para garantir as aspirações de mudança exigidas pela população.

Neste contexto, um dos grandes marcos é a aprovação da nova estrutura organizacional do Instituto de Planejamento Municipal - IPLAN, que até então estava organizado para atender às exigências do planejamento físico-territorial. Assim, a criação de duas coordenações, uma setorial e outra global, e de núcleos como "Lazer" e "Meio Ambiente" revelam as preocupações que existiam com os problemas de natureza sócio-econômicos, como também com a definição de uma metodologia de planejamento a ser adotada pelo órgão. Quanto às preocupações sócio-ambientais, houve a extensão da Rede Física Escolar e da Rede Física de Equipamentos Sociais, Cadastro de Áreas Verdes e Carta de Risco de Goiânia, e a produção 
de normas e leis regulamentando os percentuais mínimos necessários à qualidade de vida urbana.

Quanto às intervenções físicas, as de maior importância ocorreram no sistema viário. A estrutura viária de circulação e transporte foi se consolidando. As de maior relevância foram o prolongamento da Av. Goiás, da T-63 e da 136 (atual Jamel Cecílio), abertura da avenida Consolação, construção das Marginais do Córrego Botafogo e Capim Puba, bem como os programas de pavimentação asfáltica.

Em relação ao setor habitacional, na questão da regularização de posses, o Município se restringiu tão somente à elaboração de mecanismos institucionais específicos para estes assentamentos, ficando as ações de regularização propriamente ditas sob a responsabilidade do Estado. Por outro lado, a urbanização dessas áreas com os serviços urbanos necessários, tais como pavimentação, água, esgoto e equipamentos, foi sendo viabilizada pelo governo municipal, na medida em que se davam as suas aprovações.

É necessário observar que o Estado e o Município não desenvolveram uma Política Habitacional que garantisse à população de Goiânia a satisfação da expectativa da propriedade. Mesmo tendo sido produzidos, através do governo municipal, programas que viabilizariam estoque de áreas prioritárias para habitação, bem como mecanismos para a produção de moradia, estes não foram suficientes para o conjunto da população.

No entanto, é preciso ressaltar que mesmo o IPLAN tendo sido reestruturado organizacionalmente no sentido de incorporar a dimensão sócio-econômica ao planejamento, grande parte dos projetos e programas não foi implementada, por não contemplar interesses de grupos ou pessoas que exerciam algum tipo de pressão junto aos poderes Legislativo e Executivo. Dessa forma, a partir dos anos 80, o IPLAN vai perdendo suas funções quanto ao gerenciamento da cidade. O órgão passa por um processo de esvaziamento político de suas funções, acompanhado de um esvaziamento de seu quadro técnico.

Portanto, o IPLAN que havia sido constituído para gerenciar a cidade, torna-se politicamente frágil. Nesse sentido, deixa de ser o órgão responsável pelo planejamento da cidade e passa a responder pelos problemas de curto prazo. A partir de 1988 é que se retomou a discussão de um novo Plano de Desenvolvimento para a cidade, não só por exigência dos desafios urbanos que a cidade enfrenta, mas também por exigência da Constituição Federal de 1988 e da Lei Orgânica do Município de 1990. Recentemente, em janeiro de 1999, o IPLAN é reestruturado e passa a se chamar Secretaria Municipal de Planejamento - SEPLAN. 


\subsubsection{A CONTRIBUIÇÃO DO EMPREENDEDOR IMOBILIÁRIO}

Desde a fundação da Cidade, o empreendedor imobiliário sempre se vinculou ao Estado. O primeiro loteamento privado aprovado em Goiânia pertencia à empresa do primeiro governador eleito, depois da implantação da Cidade. A vinculação com o Estado apresenta uma certa relevância, na medida em que isto implica a ampliação dos lucros a serem auferidos com a produção do espaço urbano construído.

É interessante notar que até a década de 60, os empreendedores imobiliários se preocupavam fundamentalmente com o projeto e com o processo produtivo. Somente a partir de 1964, com o Banco Nacional de Habitação, é que o produto a ser mercantilizado pelo empreendedor imobiliário passa a ser produzido em função da renda do comprador. O perfil sócioeconômico do comprador passa a ser determinante. O empreendedor imobiliário, que na fase anterior se industrializara com a produção de conjuntos habitacionais e condomínios verticais para as classes de maior poder aquisitivo, tinha na produção de edifícios a principal fonte de lucro e de acumulação de capital.

O objetivo era racionalizar a obra e minimizar os custos, aumentando a taxa de exploração de mão-de-obra, diminuindo os tempos e custos de produção, sem investir em novas tecnologias ou pesquisas. O empreendedor não se limita a produzir a habitação, o lote ou a infra-estrutura, porque com o processo de concentração de rendas, aquele que pode pagar por estas mercadorias já as possui e constitui um mercado cada vez menor e mais exigente. Grande parte da população está excluída socialmente e outros tantos participam na inconstante economia informal ou em sub-empregos.

Tomou maior importância, não o planejamento da produção, não o produto a ser mercantilizado, mas o mercado, o consumidor. O restrito segmento social, com rendas capazes de adquirir um imóvel ou sua infra-estrutura urbana, é que determina as características da mercadoria imobiliária a ser produzida. A partir de 1975, incorpora na tomada de decisão, estratégias modernizadoras cujas ações deixam de ser expontâneas e passam a ser planejadas com a perspectiva de que são estas que proporcionam maior taxa de retorno.

Desta forma, para os empresários imobiliários, quem define o local e os padrões do empreendimento é o perfil do consumidor, sua faixa de renda, suas possibilidades de pagamento e seus hábitos sociais. Obviamente que a adoção de estratégia racionalizadora não exclui o "trânsito livre" junto a políticos e membros da tecno-burocracia estatal. Ao mesmo tempo em que procura oferecer uma mercadoria que seja atrativa e lucrativa, fica atento à 
ação do Estado, onde sempre é possível obter favores e informações que permitam influir de forma direta ou indireta sobre sua ação.

As ações do Estado, nesta fase, em nenhum caso prejudicou o conjunto dos empreendedores, ao contrário, sempre beneficiou um grupo deles. Neste período, vive-se uma conjuntura de crise de consumo gerado pela excessiva concentração de rendas.

A forma encontrada para atingir o objetivo empresarial de maior lucro foi estreitar o relacionamento com o Estado na perspectiva de continuar influindo nas decisões dos grandes empreendimentos. O Estado tinha certa autonomia para disciplinar a ação dos empreendedores, porém foi conivente com o desenvolvimento do processo.

\subsubsection{A CONTRIBUIÇÃO DOS POSSEIROS URBANOS}

No período de 1950 a 1964, o Estado entrou em conflito constante com os chamados invasores de terras urbanas. Nesse período, o Estado foi levado a garantir juridicamente o regime de propriedade, como forma de atender às expectativas do empreendedor imobiliário, que se sentia ameaçado por este tipo de apropriação. Porém, de 1964 a 1975, houve um aumento significativo de invasões, em áreas públicas, uma vez que o Estado defendia eficientemente a terra privada, mas era complacente com a ocupação de suas terras.

Apoiada por grupos da Igreja, esta significativa parcela da população de baixa renda se instalou em áreas com algum problema de documentação legal, passando a se fazer presente como força política e de pressão sobre o Estado. Indiretamente é o grupo social que exerce uma pressão contra o abuso indiscriminado da especulação imobiliária, da qual o empreendedor imobiliário é parte integrante direta ou indiretamente.

De 1975 aos dias atuais, aumentou o número de posseiros de terras e aconteceram as primeiras invasões organizadas, em grandes grupos, em terras privadas. O Estado acabou assumindo o ônus, desapropriando a área e legalizando as posses existentes. $\mathrm{O}$ invasor passou a ter poder de pressão sobre o Estado, chegando ao fim o período repressor de garantia da propriedade privada de terra, matéria-prima do empreendedor imobiliário. Graças a esta conquista, os espaços vazios passaram a ser ocupados mais rapidamente, com o receio de que viessem a ser invadidos.

O posseiro urbano consegue mobilizar a opinião pública a seu favor e inibe, mesmo que de forma ainda incipiente, as alianças entre agentes do Estado e da iniciativa privada. 
Deste modo, algumas ações do Estado passaram a se voltar no sentido de criar condições de assentamento desta classe de excluídos. De qualquer forma, no início dos anos 80, Goiânia passou a ter um novo agente formador do espaço urbano.

Quanto aos conceitos de "invasor" e "posseiro urbano", é importante retomar a discussão de Chaves (1985) sobre movimentos populares por moradia na Vila Formosa, na zona Sudoeste de Goiânia. Essa mobilização agrega várias atividades, quais sejam, a construção de um espaço para habitação, a organização de formas de luta para defesa desse espaço e a mudança da identidade de invasor que lhes foi imposta. Nesse sentido, esses movimentos são caracterizados por uma dimensão material, que busca a conquista e manutenção de propriedade, e uma dimensão simbólica, que pretende reconstruir sua própria identidade através do conceito de posseiro urbano.

A identidade de invasor, que havia sido construída para caracterizar os moradores destes espaços, acaba sendo utilizada por esses mesmos indivíduos para caracterizar os proprietários legais dessas áreas.

Assim, procede-se a uma inversão ideológica onde a conotação negativa atribuída aos ocupantes da invasão é transferida para o agente oposto: os proprietários. A estes são pois, atribuídas as características de "ladrões", "invasores" e "gananciosos", em suma, agentes sociais cujas ações não encontram legitimidade em seu universo de significações e em relação aos quais se estabelece as situações de enfrentamento (CHAVES, 1985, p.208).

Dessa forma, a construção da identidade de posseiro é realizada por oposição à identidade de invasor. Assim, enquanto o posseiro, em decorrência de sua situação de carência sócio-econômica, ocupa um determinado espaço por necessidade, o invasor o faz por "ganância”. À identidade de posseiro é internalizado o direito de posse, já que houve a ocupação de uma área sem traços de propriedade e sem o uso de violência. Quanto à identidade de invasor, esse não possui o direito de posse, já que a terra era utilizada somente de forma especulativa, e a tentativa de retomada é realizada através de mecanismos violentos.

Porém, essa nova identidade não é interiorizada por todo o conjunto de moradores. Há aqueles indivíduos que não se consideram proprietários do terreno ocupado e desejam a legalização através da ação do Governo e de políticos, e não pela via da ação coletiva dos moradores. Dessa forma, surge uma outra identidade, o "morador", que não participa das organizações de bairro e interioriza a característica de submissão que a sociedade lhe impôs. 


\subsection{O MUNICÍPIO DE SENADOR CANEDO}

O município de Senador Canedo se origina com a construção da estrada de ferro da Rede Ferroviária Federal S/A. Famílias de trabalhadores de Minas Gerais e Bahia se deslocavam para essa região para trabalhar na construção da ferrovia. A fazenda Vargem Bonita, do então Senador Antônio Amaro Leite Canedo, foi o local onde foram construídos os acampamentos dos trabalhadores, originando as primeiras moradias do futuro município.

A zona central e os primeiros estabelecimentos comerciais surgiram nos anos 30, em torno da Estação Ferroviária. A Igreja, na figura do padre Francisco Sales Peclat, teve papel importante no processo de ocupação espacial dessa região. Com a doação ou venda a baixos preços de lotes, surgiram os parcelamentos de São Sebastião e Esplanada. Todo o povoado passou a ser conhecido como Esplanada, sendo posteriormente denominado de Senador Canedo, em homenagem ao político goiano.

Em 31 de março de 1953, o povoado, pertencente ao município de Goiânia, é elevado à condição de distrito, surgindo o cargo de subprefeito e o cartório. Em 09 de janeiro de 1988, a Assembléia Legislativa de Goiás aprovou a emancipação do município, abrangendo a região do antigo distrito de Goiânia e áreas dos municípios de Bela Vista de Goiás e Aparecida de Goiânia. A instalação do município foi efetivada em $1^{\circ}$ de junho de 1989.

O Censo Demográfico do IBGE de 1980 contabilizou uma população de 3.042 habitantes, sendo 824 na zona urbana e 2.218 na zona rural. O Censo de 1991 calculou 23.905 habitantes, sendo 8.753 na área urbana e 15.152 na área rural. A participação do sexo masculino foi de 12.134 , e do sexo feminino, de 11.771 pessoas. A contagem populacional de 1996 computou 44.266 pessoas, 41.384 na zona urbana e 2.882 na zona rural, sendo 22.124 homens e 22.142 mulheres. Por fim, a contagem populacional de 1999 registrou 55.506 habitantes. Para uma melhor visualização dos dados, eles foram organizados nas tabelas a seguir. Algumas células não apresentam os dados, pelo fato de a fonte consultada não fornecer todas as informações (COSTA, 1997) e porque os dados da contagem populacional de 1999 ainda não foram divulgados na totalidade pelo IBGE. 
TABELA 4.2.1 - População residente, por situação de domicílio

\begin{tabular}{c|c|c|c}
\hline ANO & ZONA URBANA & ZONA RURAL & TOTAL \\
\hline 1980 & $\mathbf{2 7 , 0 9 \%}$ & $\mathbf{7 2 , 9 1 \%}$ & $100,0 \%$ \\
& $(824)$ & $(2.218)$ & $(3.042)$ \\
\hline 1991 & $\mathbf{3 6 , 6 2 \%}$ & $\mathbf{6 3 , 3 8 \%}$ & $100,0 \%$ \\
& $(8.753)$ & $(15.152)$ & $(23.905)$ \\
\hline 1996 & $\mathbf{9 3 , 4 9 \%}$ & $\mathbf{6 , 5 1 \%}$ & $100,0 \%$ \\
& $(41.384)$ & $(2.882)$ & $(44.266)$ \\
\hline 1999 & - & - & $100,0 \%$ \\
& & & $(55.506)$ \\
\hline
\end{tabular}

Fonte: IBGE - Censos Demográficos de 1980 e 1991 e contagem populacional de 1996 (apud COSTA, 1997). E dados preliminares do IBGE da contagem populacional de 1999.

TABELA 4.2.2 - População residente, por sexo

\begin{tabular}{c|c|c|c}
\hline ANO & MASCULINO & FEMININO & TOTAL \\
\hline 1980 & - & - & $100,0 \%$ \\
& & & $(3.042)$ \\
\hline 1991 & $\mathbf{5 0 , 7 6 \%}$ & $\mathbf{4 9 , 2 4 \%}$ & $100,0 \%$ \\
& $(12.134)$ & $(11.771)$ & $(23.905)$ \\
\hline 1996 & $\mathbf{4 9 , 9 8 \%}$ & $\mathbf{5 0 , 0 2 \%}$ & $100,0 \%$ \\
& $(22.124)$ & $(22.142)$ & $(44.266)$ \\
\hline 1999 & - & - & $100,0 \%$ \\
& & & $(55.506)$ \\
\hline
\end{tabular}

Fonte: IBGE - Censos Demográficos de 1980 e 1991 e contagem populacional de 1996 (apud COSTA, 1997). E dados preliminares do IBGE da contagem populacional de 1999.

TABELA 4.2.3 - População residente, por situação de domicílio e sexo

\begin{tabular}{c|r|r|r|r|r|r|r}
\hline \multirow{2}{*}{ ANO } & \multicolumn{3}{|c|}{ ZONA URBANA } & \multicolumn{3}{c|}{ ZONA RURAL } & \multirow{2}{*}{ TOTAL } \\
\cline { 2 - 7 } & Total & Masculino & Feminino & Total & Masculino & Feminino & \\
\hline 1980 & 824 & - & - & 2.218 & - & - & 3.042 \\
\hline 1991 & 8.753 & 4.459 & 4.294 & 15.152 & 7.675 & 7.477 & 23.905 \\
\hline 1996 & 41.384 & 20.587 & 20.797 & 2.882 & 1.537 & 1.345 & 44.266 \\
\hline 1999 & - & - & - & - & - & - & 55.506 \\
\hline
\end{tabular}

Fonte: IBGE - Censos Demográficos de 1980 e 1991 e contagem populacional de 1996 (apud COSTA, 1997). E dados preliminares do IBGE da contagem populacional de 1999.

Os dados referentes a sexo não trazem maiores informações, já que a população é dividida de forma equilibrada entre homens e mulheres. Os dados de situação de domicílio ilustram que a população, predominantemente rural em $1991-63,38 \%$-, passa a se concentrar no meio urbano em 1996, com 93,49\% dos habitantes. Isso ocorreu porque, com a criação do 
município, grande parte da área rural foi loteada e urbanizada, ocasionando ainda a diminuição da atividade agropecuária na região.

A queda acentuada [da exploração agrícola] somente foi sentida com a criação do município, em 1988. Conforme observou-se, a pressão por moradia na capital levou os governos central, estadual e municipal a posicionarem-se pela explosão imobiliária em Senador Canedo, com vistas a estancar o inchaço da capital (COSTA, 1997, p.19).

Mesmo com o grande processo de urbanização em curso, a organização espacial do município encontra-se ligada à agropecuária. A zona rural é destinada, quase em sua totalidade, à lavoura e à pastagem. Existem ainda vários loteamentos denominados chácaras de recreio, que são utilizados em finais de semanas, e seus proprietários são residentes em Goiânia. A zona urbana é formada por uma área-sede, onde se encontram instalados os poderes públicos municipais e o comércio em geral. Além disso, junto aos limites do município de Goiânia, existem bairros periféricos isolados, cuja utilização é estritamente residencial. Atualmente, o município conta com 49 bairros, alguns com crescimento desordenado e não-autorizados legalmente.

Quanto ao setor industrial, a política de fomento à industrialização do Estado beneficiou Senador Canedo com a implantação do Distrito Industrial de Goiânia, em 1968, e de indústrias frigoríficas. Porém, somente após sua emancipação política, Senador Canedo passou a receber investimentos empresariais, somando, em 1997, um total de 20 estabelecimentos industriais, entre eles o Pólo Coureiro e Calçadista de Goiás, o Terminal de Distribuição de Derivados de Petróleo e várias micro-empresas. Quanto ao setor de comércio e serviços, este passou por um grande desenvolvimento, acompanhando o crescimento demográfico da região. É importante salientar que, conforme afirma Costa (1997), a maior parte das empresas do setor de serviços opera em Goiânia, mas mantém o endereço em Senador Canedo para fugir dos impostos.

A seguir são apresentados um mapa das cidades vizinhas a Senador Canedo (COSTA, 1997, p.40) e dois mapas desse município (SANTOS, 1994, p.10 e 22), ilustrando seus aspectos fisiográficos e a apropriação de seu espaço. 


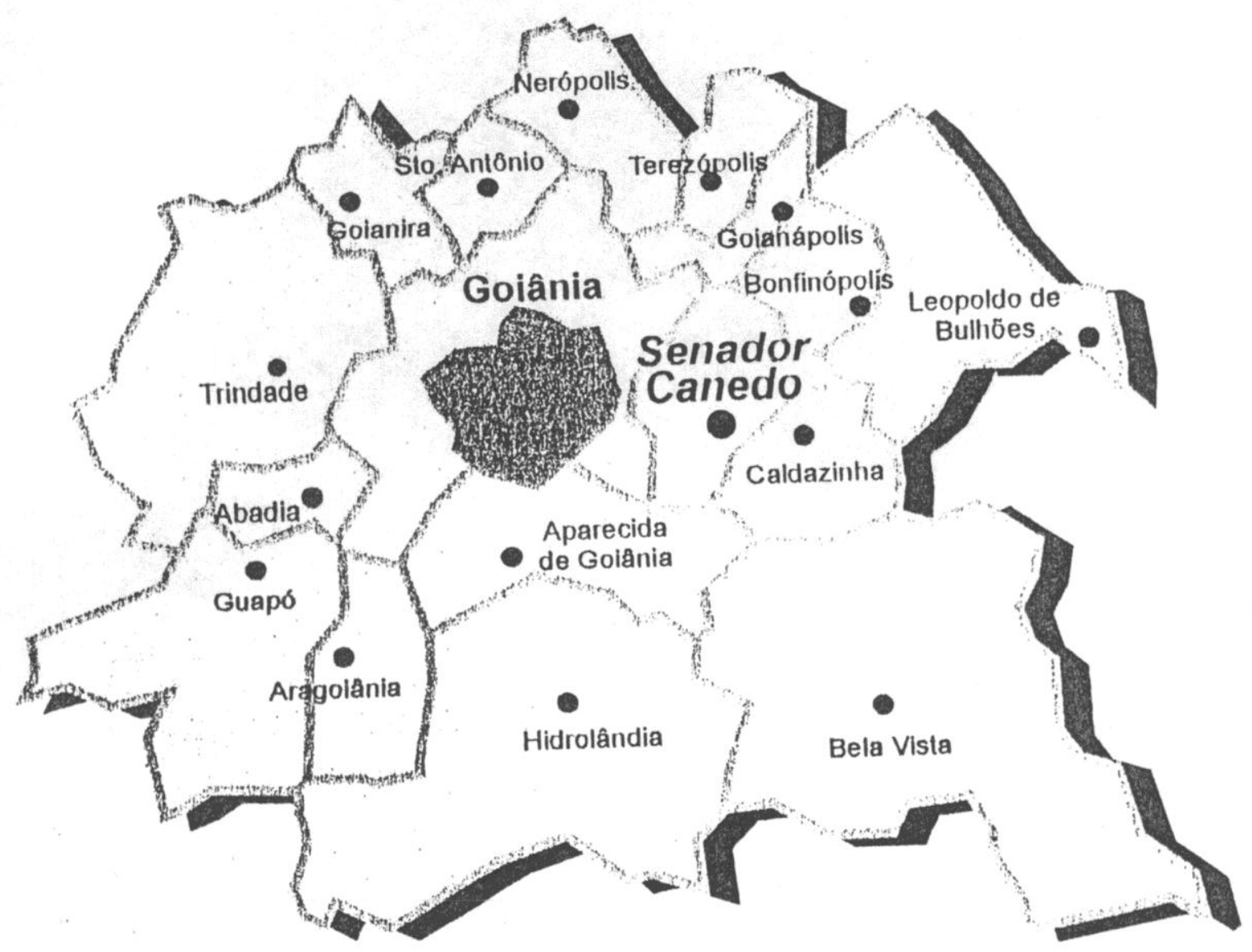

Fonte: COSTA, Francisco de Assis Gomes. Informações socioeconômicas municipais de Senador Canedo. Goiânia: SEBRAE/GO, 1997. p.40 
MAPA II - Aspectos fisiográficos do município de Senador Canedo

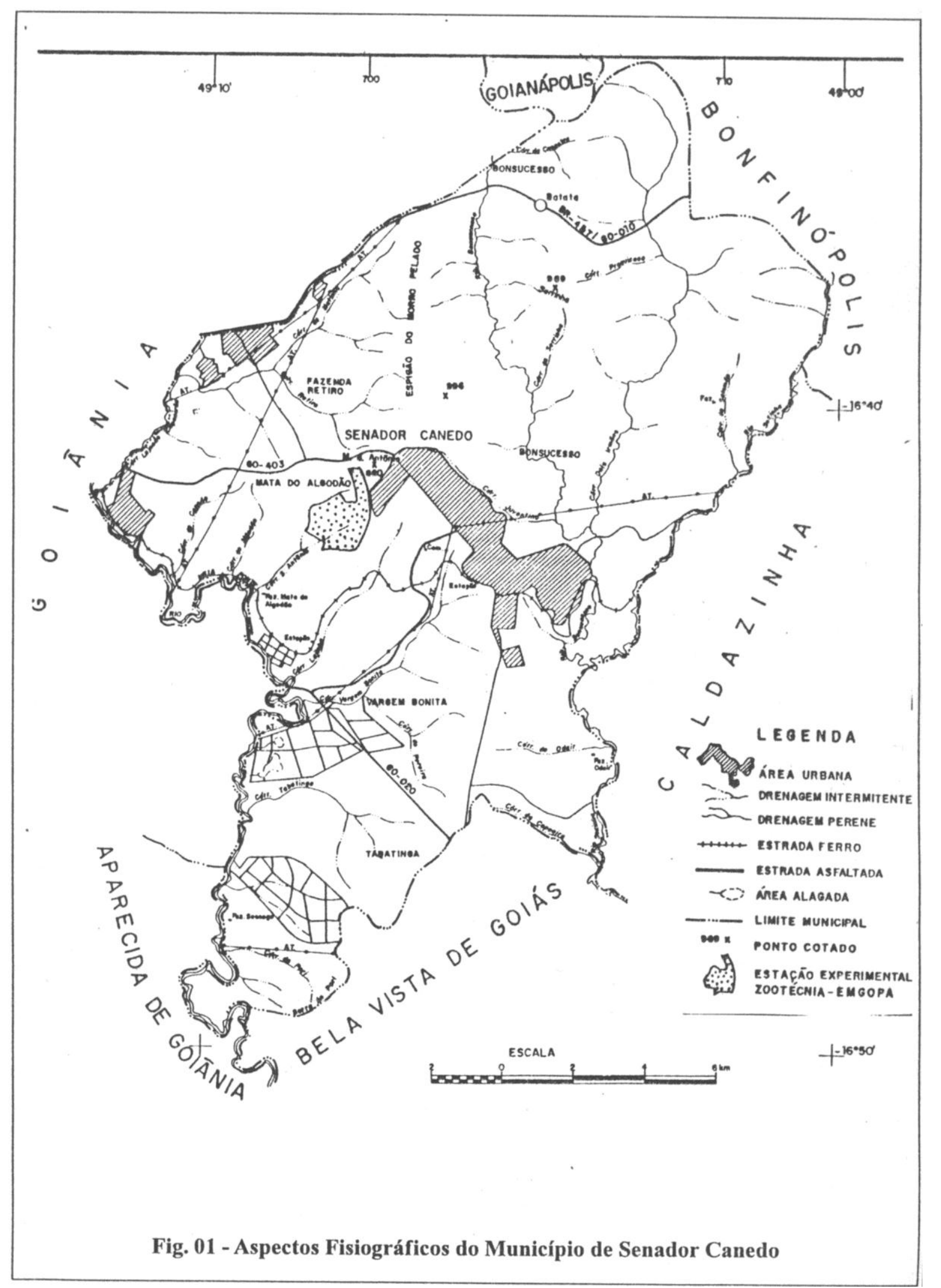

Fonte: SANTOS, Levi Makert dos e outros. Sistemas de informações municipais - Zoneamento geoambiental Senador Canedo. Goiânia: FINEP/EMGOPA/IBGE, 1994. p.10. 


\section{MAPA III - Apropriação do espaço do município de Senador Canedo}

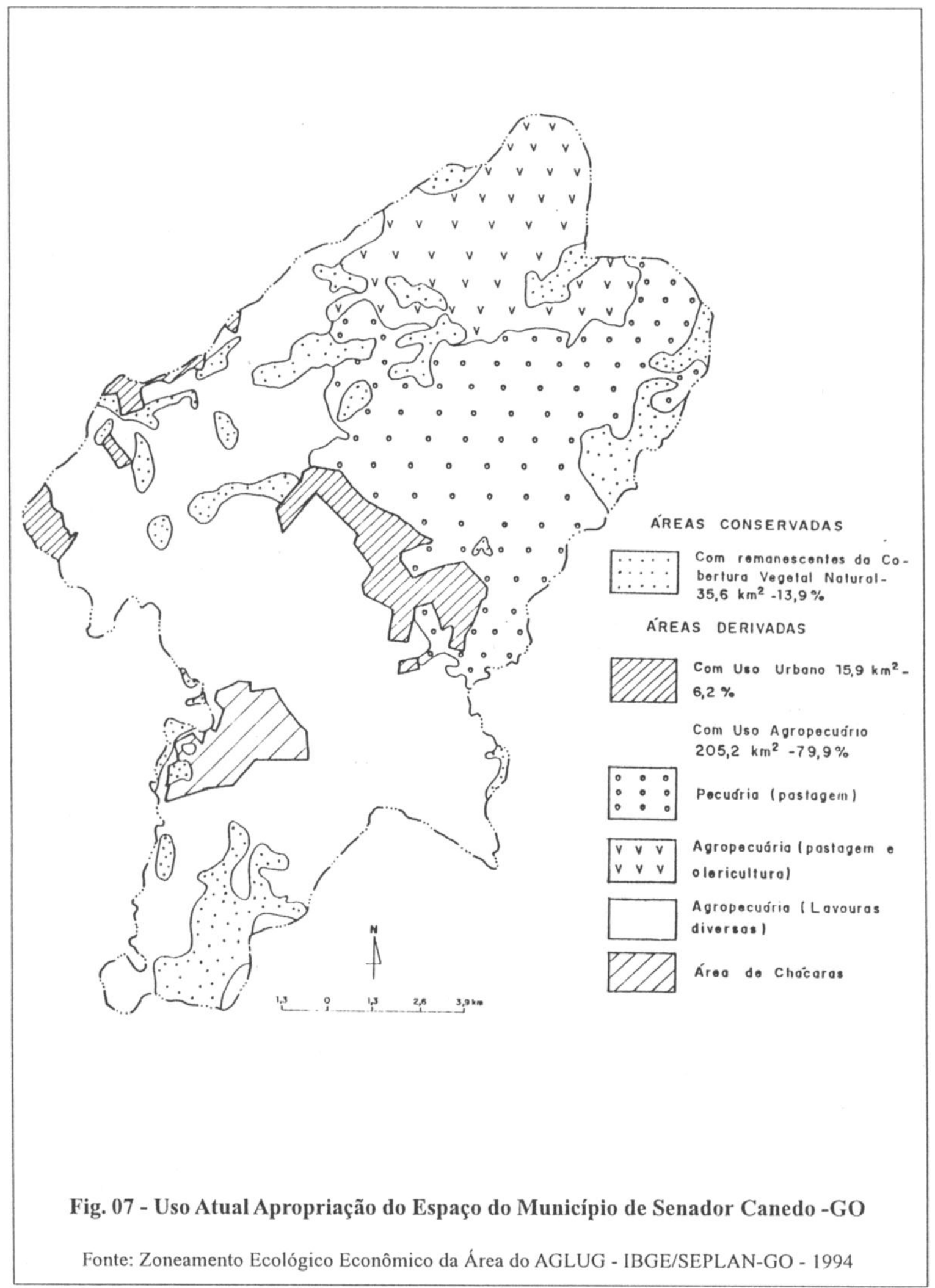

Fonte: SANTOS, Levi Makert dos e outros. Sistemas de informações municipais - Zoneamento geoambiental Senador Canedo. Goiânia: FINEP/EMGOPA/IBGE, 1994. p.22. 


\subsection{OBJETIVAÇÃO DO PROBLEMA}

A partir dos dados do Censo Demográfico de 1991 e da contagem populacional de 1999, apresentados anteriormente, temos que a população de Senador Canedo cresceu de 23.905 para 55.506 habitantes, em 8 anos. Isso significa uma taxa média de crescimento anual da população de $16,52 \%$. Percebe-se, então, que esse município está em amplo crescimento demográfico. O que resta agora saber é de que forma Senador Canedo está inserido na estruturação urbana e na mobilidade espacial da região metropolitana de Goiânia.

Quais seriam os fatores que estariam influindo para esse aumento desenfreado da população? Quais seriam as regiões de origem desse novo contingente populacional? Seriam esses novos habitantes provenientes de outros Estados ou da própria região metropolitana de Goiânia? Qual seria a utilização que a população de Senador Canedo está fazendo da cidade? O município seria simplesmente uma "cidade-dormitório"? Ou o fato de seu setor secundário estar se fortalecendo estaria transformando a configuração sócio-econômica dessa área? E ainda, essa mobilidade residencial estaria alterando a configuração sócio-espacial da região metropolitana de Goiânia? 


\section{METODOLOGIA}

\subsection{MOBILIDADE ESPACIAL E ESTRUTURAÇÃO SÓCIO-ESPACIAL: CONS- TRUÇÃO DE UM MODELO}

O fenômeno da mobilidade espacial, entendido aqui como importante componente do processo de organização social e, especificamente, da dinâmica urbana, perpassa toda a discussão em torno das alterações na estrutura social e espacial nos países centrais e periféricos. Numa dimensão mais ampla, a crise e a reestruturação econômica mundial têm se traduzido em nova motivação e no redirecionamento dos deslocamentos espaciais dos trabalhadores, que ultrapassam as fronteiras regionais e nacionais. Na dimensão urbana, a formação dos enclaves residenciais, sejam guetos, favelas ou condomínios de alta renda, assim como os processos de periferização acionam dinâmicas de expulsão e atração populacional específicas que, por sua vez, interferem na reestruturação espacial em curso. É nessa perspectiva que incorpora-se no debate os deslocamentos populacionais, intra-urbanos e inter-regionais, inerentes a essas mudanças.

Antes de tudo, duas questões de ordem teórico-metodológica devem ser apresentadas. A primeira diz respeito ao fato de a mobilidade espacial dos homens ser indissociável da mobilidade espacial dos bens de consumo e de produção, de capitais, de empresas, de tecnologias e de informações. No caso da mobilidade intra-urbana, a localização e relocalização do capital imobiliário e dos investimentos públicos na cidade assumem papel de destaque. A segunda questão refere-se à associação da mobilidade espacial a dois outros tipos de mobilidade: a profissional e a social. Os movimentos migratórios em direção aos centros urbanos estão normalmente relacionados às mudanças de emprego e de posição na estrutura social, que podem ser ascendentes ou descendentes. A mobilidade intra-urbana, por sua vez, está mais fortemente associada à mobilidade social, que, além da dimensão objetiva atrelada às condições sócio-econômicas dos que se deslocam, contém forte conotação subjetiva relativa à divisão simbólica do espaço urbano e a determinados valores. Nesse caso, é grande a complexidade da análise, em função da diversidade e da subjetividade dos indicadores de ascensão ou descensão social relacionados à mobilidade residencial intra-urbana.

Na perspectiva da interação da estruturação sócio-espacial com os deslocamentos populacionais, o fenômeno da mobilidade espacial tem sido muito pouco explorado, aparecendo 
de forma implícita nos estudos sobre a dinâmica urbana. Os trabalhos enfatizam fatores explicativos da mobilidade, através de modelos causais que articulam diferentes variáveis, dependendo dos pressupostos teóricos que alimentam as análises.

As abordagens de cunho marxista consideram a mobilidade espacial numa perspectiva macro-socioeconômica, através da qual existe um nexo estrutural entre esse fenômeno e a mobilidade do trabalho necessária à reprodução do capital. Privilegiam-se os deslocamentos inter-regionais e internacionais, ligados à concentração/desconcentração das atividades econômicas e à emergência de novos espaços de trabalho. Nessa perspectiva, haveria dois tipos de mobilização do trabalho com implicações diretas sobre a migração. A primeira refere-se à mobilidade que joga no mercado de trabalho uma quantidade de homens livres e móveis que vão emigrar de zonas geográficas fora da esfera do capital. Numa segunda etapa, ocorre o segundo tipo de mobilização do trabalho, referente à mobilidade do trabalhador entre os diferentes setores de atividade no interior do mercado, que implica igualmente numa migração, mas no interior da esfera do capital. Nos países periféricos, esses dois tipos de mobilização do trabalho muitas vezes se sobrepõem, na medida em que há uma permanente mobilidade para dentro e para fora dos setores econômicos capitalistas, assim como entre esses setores. Mesmo com essa sobreposição, parte da migração campo-cidade estaria relacionada à liberação de trabalhadores rurais que procurarão inserir-se no mercado de trabalho, bem como parte da migração metrópole-interior estaria relacionada à reestruturação produtiva e ao novo papel econômico dos grandes centros.

Nessa escala de análise, a abordagem marxista se contrapõe à perspectiva neoclássica, em que a mobilidade espacial é entendida como resultado das diferenças regionais do salário. Enfatizam-se as oportunidades econômicas como determinantes do volume e da orientação dos fluxos populacionais, oportunidades que serão escolhidas racionalmente pelos trabalhadores a partir de uma avaliação de custo e benefício. Num mercado em equilíbrio concorrencial (pressuposto neoclássico), essas diferenças e a migração tenderiam a desaparecer.

$\mathrm{Na}$ escala intra-urbana, três vertentes de análise da mobilidade espacial merecem ser observadas. A primeira centra-se nas regularidades dos padrões de mobilidade, numa abordagem descritiva na qual não se buscam os fatores explicativos do fenômeno estudado. A regularidade mais significativa verificada nesses estudos é a tendência das famílias de se mudarem para áreas de status sócio-econômico similar. As diferenças de rendimento entre as famílias, assim como os preços imobiliários, estão dados a priori, e os fluxos populacionais intra- 
urbanos são altamente previsíveis. Trata-se de uma leitura ecológica do espaço urbano, na qual a cidade é fracionada em áreas socialmente homogêneas em termos de renda, ocupação, tipo de residência, etnia, ciclo de vida, entre outras variáveis, e em que essa segregação espacial é resultante essencialmente do diferencial da capacidade de cada grupo social em pagar pela residência que ocupa. A mobilidade residencial reproduz o padrão de segregação existente.

Com base nos princípios ecológicos, estudos descritivos foram realizados na América Latina, nos anos 70, com o objetivo de apurar as regularidades identificadas pela teoria da ecologia humana no que diz respeito à localização espacial dos migrantes e seus movimentos no âmbito da cidade latino-americana. Segundo esse pensamento, a forma assumida pelos assentamentos urbanos representa a acomodação da organização social a seu meio ambiente físico. Explicitando as fases por que passou a ecologia urbana, Gottdiener argumenta:

A primeira [fase] constitui o modo como a Escola de Chicago anterior à Segunda Guerra Mundial aborda a teoria, o qual se concentrou em fatores behavioristas ou sociobiogênicos para explicar os padrões espaciais; a segunda, a perspectiva do pós-guerra, localizada em vários lugares, que enfatiza uma visão sistêmica daqueles ajustamentos da sociedade ao meio ambiente que são uma consequiência de forças sociais básicas, como a competição econômica (GOTTDIENER, 1997, p.37).

No âmbito latino-americano, a regularidade mais comum difundida por essa literatura é a de que os migrantes tenderiam a se localizar, à chegada, nas zonas centrais da cidade e, mais tarde, concomitantemente a uma mobilidade sócio-econômica, se mudariam para áreas periféricas. A idéia da zona central como área de transição e de recepção de migrantes pobres foi descartada. Assim, as áreas centrais teriam perdido sua função de receptora dos migrantes pobres, os quais estariam residindo predominantemente nas ocupações ilegais nas áreas periféricas.

A segunda vertente de análise sobre a mobilidade intra-urbana reúne um conjunto de estudos estatísticos, em sua maioria americanos, centrados nos modelos causais de correlação entre diferentes variáveis (tais como características sócio-econômicas, demográficas e habitacionais) e os deslocamentos espaciais. Esses estudos se utilizam, normalmente, de dados agregados (como Censos Demográficos) que permitem observar o padrão geral de mobilidade, percebido como o resultado coletivo das decisões individuais de mudar de residência. A mobilidade é interpretada como um fenômeno do mercado imobiliário, em que a oferta de moradia é tratada como uma variável constante e a mudança de residência, como uma forma de comportamento adaptativo das famílias ao quadro de ofertas. 
Essas pesquisas apontam algumas correlações passíveis de generalização: o status sócio-econômico da família (renda, instrução e ocupação) determina primeiramente a qualidade da habitação comprada; e a correlação entre o status sócio-econômico da família e a mobilidade residencial é pouco consistente estatisticamente, na medida em que alguns estudos sugerem a relação entre alta taxa de mobilidade e alta renda familiar, enquanto outros apontam a relação inversa. A idéia que orienta as pesquisas é a de um espaço urbano que se estrutura através de um permanente processo adaptativo das famílias ao estoque habitacional. A demanda e a oferta de moradia estão dadas, mas se excluem das análises os processos de formação e produção dessa estrutura espacial, especialmente as racionalidades que movem esses processos. A mobilidade residencial é o objeto central dos estudos, mas não são considerados os impactos da mobilidade sobre a estruturação urbana.

A última vertente que se detém sobre o fenômeno da mobilidade residencial, parte do princípio de que ele é um fenômeno demográfico. Concentra-se em duas problemáticas para analisar a especificidade dos comportamentos demográficos nas cidades: a influência do quadro urbano sobre a mobilidade e a contribuição da mobilidade para o perfil dos bairros e unidades urbanas. Diferentemente da abordagem comportamental, que utiliza conceitos da Psicologia, essa vertente procura articular métodos qualitativos e quantitativos, baseados em análises longitudinais da mobilidade, que permitam traçar a trajetória residencial das famílias em direção à cidade e em seu interior ao longo do tempo.

Nesse caso, as representações e comportamentos residenciais dos indivíduos são examinados frente aos constrangimentos impostos pelos grupos imobiliários, pelas empresas e pelos poderes públicos, responsáveis pela segmentação do mercado de moradia. Por outro lado, os elementos explicativos clássicos, como a estrutura de oferta e o crédito bancário, não permitem compreender as estratégias residenciais em sua complexidade. Trata-se de uma abordagem centrada nos indivíduos, vistos como atores de práticas residenciais e com liberdade relativa de escolha locacional em função dos processos econômicos, sociais e culturais que estruturam o espaço residencial das cidades. O processo de produção do espaço urbano está inserido na análise, mas na perspectiva de impor constrangimentos às escolhas individuais ou familiares.

No Brasil, o tema da mobilidade residencial tem sido muito pouco abordado, aparecendo de forma implícita ou secundária nos estudos urbanos. Mais recentemente, a produção acadêmica em torno das novas tendências da urbanização brasileira e das mudanças no padrão 
de segregação espacial nas grandes metrópoles reintroduziu o fenômeno da mobilidade intraurbana, como elemento constituinte do processo de estruturação urbana. O novo padrão de segregação, nos anos 80, apresenta a manutenção da pobreza pelo tecido urbano através de um deslocamento populacional para a periferia e um retorno para os cortiços nas áreas mais centrais. Por outro lado, há uma produção de condomínios fechados nas áreas periféricas, destinados à classe média, que está empobrecida e à procura da casa própria a custos mais baixos.

Em sua tese de doutorado de 1987, voltada especificamente para a mobilidade espacial intra-urbana, Bógus (apud LAGO, 1998) procurou avaliar os impactos da política urbana sobre as condições de vida da classe trabalhadora, através de uma pesquisa longitudinal na qual se analisou a trajetória intra-metropolitana da população residente numa área periférica do Município de São Paulo - Vila do Encontro - que foi objeto de um programa de reurbanização. O estudo acompanhou os efeitos dessa intervenção tanto nas famílias que permaneceram na área como nas que dela saíram. É interessante destacar dessa abordagem a possibilidade lançada por uma análise mais minuciosa de compreender os mecanismos de interação de um conjunto de processos que agem na conformação do espaço urbano. No caso, a ação do Estado através de um programa de reurbanização local abriu novo espaço de expansão para o capital imobiliário, que, ao gerar a valorização fundiária da área, acionou através do mercado dois processos concomitantes de deslocamento espacial: a expulsão de parcela dos moradores de menor poder aquisitivo para periferias mais distantes e a atração de um novo segmento social de mais alta renda. A mobilidade residencial foi acompanhada, portanto, por alterações na configuração sócio-espacial da Cidade de São Paulo.

Num outro trabalho recente, Teixeira e Souza (1997) pretendem construir um modelo sociológico para a explicação de relações e interações humanas no espaço urbano, a partir do estudo da mobilidade sócio-espacial na Região Metropolitana de Belo Horizonte (RMBH). Para isso, os autores analisam dados dos Censos Demográficos e da Caderneta do Recenseador do IBGE, resultados da Pesquisa Origem e Destino na RMBH da TRANSMETRO e PLAMBEL e dados do Censo Demográfico trabalhados pela Fundação João Pinheiro. Dessa forma, são analisados dados de crescimento demográfico, de população residente nos municípios e administrações regionais da RMBH, de densidades demográficas nas unidades espaciais de Belo Horizonte, de tempo de residência das famílias por unidades espaciais, de distribuição das famílias segundo origem e destino dos deslocamentos, de distribuição da população segundo renda e tempo de residência, de distribuição dos domicílios segundo tipo de ocu- 
pação e renda do chefe. A conclusão do trabalho é de que o "núcleo central" está se especializando como um lugar de serviços e comércio, com uma diminuição de sua população, a qual está privilegiando conforto e segurança. E quanto às periferias, observa-se um empobrecimento e favelização, levando à acentuação da segregação social na RMBH a partir dos anos 80 .

O trabalho de Lago (1998) pretende analisar as mudanças e permanências no quadro de desigualdades sócio-espaciais na Região Metropolitana do Rio de Janeiro, durante a década de 80. Para isso, a autora divide o espaço intra-metropolitano em nove grandes áreas. Cinco áreas no interior do Município do Rio de Janeiro: Zona Sul, Zona Oeste, Centro e adjacências, Subúrbio 1 e Subúrbio 2, e uma área que equivale ao Município de Niterói. As outras três áreas reúnem municípios cujo critério de agregação foi a taxa de crescimento anual da população na década de 80: Periferia consolidada, com crescimento inferior a $1 \%$ ao ano; Periferia em consolidação, com crescimento entre $1 \%$ e $2 \%$ ao ano; e Periferia em expansão, com taxa superior a $2 \%$ ao ano. Tendo como principais fontes de informação os Censos Demográficos de 1980 e 1991, a autora concluiu que a população metropolitana empobrece e a atratividade da metrópole entra em declínio. A favelização e a periferização se mantêm, mas os efeitos da migração inter-regional sobre o quadro de desigualdades sociais se reduzem. Quanto aos deslocamentos intra-metropolitanos, a crise habitacional e a valorização da terra em regiões como Niterói, Nilópolis e São Gonçalo foram responsáveis pela intensificação e orientação dos fluxos de pessoas no interior da metrópole. Além disso, houve uma manutenção da estrutura dual, ao mesmo tempo em que o espaço metropolitano se fragmentou em enclaves.

Desse modo, na interação do processo de estruturação urbana com a mobilidade espacial, os deslocamentos residenciais, regulados pelas racionalidades da estrutura sócioeconômica e da dinâmica urbana, interferem na reestruturação sócio-espacial das cidades. 


\subsection{ESTRATÉGIA DE PESQUISA}

Primeiramente, será realizada uma revisão bibliográfica sobre o tema da mobilidade sócio-espacial no meio urbano. De posse desse material, será possível avaliar melhor as formas de investigação e as técnicas mais apropriadas para o presente estudo.

Além desse material, é importante restaurar, em profundidade, a história de criação e estruturação do município de Senador Canedo. Para isto, é necessário relembrar e analisar as políticas públicas governamentais, as ações de empreendedores imobiliários e os movimentos populares ocorridos nessa região. Isto propiciará o entendimento das articulações que fizeram parte da construção dessa cidade, não limitando-se a uma análise meramente descritiva. Quanto aos movimentos populares, é importante realizar entrevistas com seus participantes, ou com antigos membros de organizações passadas, para que se perceba como tais movimentos influíram na conformação do espaço.

Posteriormente, é preciso analisar os dados dos Censos Demográficos a partir de técnicas estatísticas apropriadas para, num primeiro momento, estabelecer correlações entre diferentes variáveis e os deslocamentos espaciais. Mas como forma de analisar os impactos da mobilidade sobre a estruturação urbana, não limitando-se à percepção da influência do espaço urbano sobre a mobilidade, é necessário ir além dos dados dos Censos.

Desse modo, é necessário realizar uma pesquisa longitudinal, para se avaliar a trajetória inter-regional e intra-metropolitana da população de Senador Canedo. Assim, além de avaliar as conseqüências das políticas governamentais, torna-se importante a realização de entrevistas com moradores da região, bem como, na medida do possível, com antigos moradores, resgatando suas histórias de vida. Assim, pretende-se compreender uma série de processos que articularam-se na configuração do espaço urbano.

Portanto, através da análise desse material coletado, os fatores do crescimento populacional e as regiões de origem da nova população de Senador Canedo estariam sendo delineados, assim como a forma como vem sendo utilizado o espaço urbano. Mas, além disso, a redação final da pesquisa explicitaria a maneira como a mobilidade residencial está modificando a configuração sócio-espacial da região metropolitana de Goiânia. 
VI. CRONOGRAMA

\begin{tabular}{|c|c|c|c|c|c|c|c|c|c|c|c|c|}
\hline ATIVIDADE & JAN & FEV & MAR & ABR & MAI & JUN & JUL & AGO & SET & OUT & Nov & DEZ \\
\hline $\begin{array}{l}\text { Revisão e análise bibli- } \\
\text { ográfica }\end{array}$ & & & & & & & & & & & & \\
\hline $\begin{array}{l}\text { Estudar a história de } \\
\text { Senador Canedo }\end{array}$ & & & & & & & & & & & & \\
\hline $\begin{array}{l}\text { Definição de técnicas } \\
\text { estatísticas para análise } \\
\text { dos dados dos Censos } \\
\text { Demográficos }\end{array}$ & & & & & & & & & & & & \\
\hline $\begin{array}{l}\text { Análise dos dados dos } \\
\text { Censos Demográficos }\end{array}$ & & & & & & & & & & & & \\
\hline $\begin{array}{l}\text { Redação parcial dos } \\
\text { resultados obtidos }\end{array}$ & & & & & & & & & & & & \\
\hline $\begin{array}{l}\text { Definição da amostra- } \\
\text { gem de entrevistas a } \\
\text { serem aplicadas e elabo- } \\
\text { ração dos roteiros }\end{array}$ & & & & & & & & & & & & \\
\hline $\begin{array}{l}\text { Realização de entrevis- } \\
\text { tas com participantes de } \\
\text { movimentos populares e } \\
\text { demais habitantes }\end{array}$ & & & & & & & & & & & & \\
\hline $\begin{array}{l}\text { Transcrição e análise } \\
\text { das entrevistas }\end{array}$ & & & & & & & & & & & & \\
\hline Redação final & & & & & & & & & & & & \\
\hline
\end{tabular}




\section{REFERÊNCIAS BIBLIOGRÁFICAS}

ARANTES, Celimene Machado de Faria e outros. Plano de desenvolvimento integrado de Goiânia. Goiânia: Instituto de Planejamento Municipal - IPLAN, 1992.

CAMPOS, Francisco Itami e BERNARDES, Genilda D'Arc. Goiânia: sociabilidade na periferia. Ciências Humanas em Revista, Goiânia, v.2, n.1/2, p.13-46, jan./dez. 1991.

CHAVES, Elza Guedes. De invasor a posseiro: Estado-Igreja e a luta pela terra urbana. João Pessoa, 1985. Dissertação (Mestrado em Ciências Sociais) - Centro de Ciências Humanas, Letras e Artes, Universidade Federal da Paraíba. Cap.V.

COSTA, Francisco de Assis Gomes. Informações socioeconômicas municipais de Senador Canedo. Goiânia: SEBRAE/GO, 1997.

GOTTDIENER, Mark. A produção social do espaço urbano. 2.ed. São Paulo: Edusp, 1997.

LAGO, Luciana Corrêa do. Estruturação urbana e mobilidade espacial: uma análise das desigualdades socioespaciais na metrópole do Rio de Janeiro. São Paulo, 1998. Tese (Doutorado em Estruturas Ambientais Urbanas) - Faculdade de Arquitetura e Urbanismo, Universidade de São Paulo.

LIPIETZ, Alain e LEBORGNE, Danièle. O pós-fordismo e seu espaço. Espaço \& Debates, Rio de Janeiro, n.25, p.12-29, 1988.

RABELO, Francisco Chagas Evangelista. Pesquisa de indicadores sociais - Goiânia e cidades do entorno. Goiânia, 1999. Projeto de pesquisa - Faculdade de Ciências Humanas e Filosofia, Universidade Federal de Goiás. 
RIBEIRO, Luiz César de Queiroz. Reforma urbana na cidade da crise: balanço teórico e desafios. In: RIBEIRO, Luiz César de Queiroz e SANTOS Jr., Orlando Alves dos (orgs.). Globalização, fragmentação e reforma urbana: o futuro das cidades brasileiras na crise. 2.ed. Rio de Janeiro: Civilização Brasileira, 1997.

SANTOS, Levi Makert dos e outros. Sistemas de informações municipais - Zoneamento geoambiental Senador Canedo. Goiânia: FINEP/EMGOPA/IBGE, 1994.

SASSEN, Saskia. A cidade global. In: LAVINAS, Lena e outros. Reestruturação do espaço urbano e regional no Brasil. São Paulo: HUCITEC/ANPUR, 1993. p.187-202.

TEIXEIRA, João Gabriel e SOUZA, José Moreira de. Desigualdade sócio-espacial e migração intra-urbana na Região Metropolitana de Belo Horizonte 80-91. Caxambu, 1997. Trabalho acadêmico (Paper apresentado no XXI Encontro Anual da Associação Nacional de Pós-Graduação e Pesquisa em Ciências Sociais - ANPOCS).

Universidade Federal do Paraná. Biblioteca Central. Normas para apresentação de trabalhos. 5.ed. Curitiba: Ed. UFPR, 1995. v.2, 6 e 7.

VERGARA, Rodrigo e ACCORSI, Fabiano. Grande São Paulo do século 21 invade limites e alcança Campinas. Folha de São Paulo, São Paulo, 24 de janeiro de 1999. Cotidiano, v.3, p. 1 . 